\title{
Is Vote Buying Effective? Evidence from a Field Experiment in West Africa*
}

\author{
Pedro C. Vicente ${ }^{1}$ \\ JOB MARKET PAPER \\ First Draft: January 2007; This Draft: October 2007
}

\begin{abstract}
:
Crude vote buying is a frequent practice during election time in many parts of the world, namely in Africa. But no research has been done to quantify its effects on voters' electoral behavior. To address this challenge, we designed and conducted a randomized experiment during the presidential elections of July 2006 in Sao Tome and Principe. This is a newly found oil-rich West African country that has been facing an increase in door-to-door vote buying. Our research design included a randomized campaign against vote buying sponsored by the Electoral Commission of the country, and pre-electoral campaign/postelection panel surveys in treatment (exposed to the campaign) and control locations, including 1034 subjects across 50 different areas. We observe a significant effect of the campaign on perceptions of vote buying, which constitutes the exogenous variation we use to identify effects on voting behavior. We characterize determinants of vote buying (more frequent in swing and rural locations), and find that vote buying energizes the electorate by increasing turnout. Crucially, we capture real effects on candidates' relative performance, by identifying the challenger to be driving more votes through vote buying (after the treatment), which is consistent with the timeline of events (late challenger candidacy). These results control (by design) for conformity biases induced by the treatment upon respondents, and are robust to changes in information about the candidates (e.g. policy platforms) and location-specific minutes spent by international electoral observers.
\end{abstract}

JEL Codes: D72, O55, P16.

Keywords: Vote Buying, Electoral Politics, Political Economy, Randomized Experiment, Field Experiment, Sao Tome and Principe, West Africa

\footnotetext{
* I wish to thank Abigail Barr, Cátia Batista, Robert Bates, Tim Besley, Paul Collier, Esther Duflo, Marcel Fafchamps, John Gerring, Macartan Humphreys, Rocco Macchiavello, Casey Mulligan, Roger Myerson, Rohini Pande, Torsten Persson, Gerhard Seibert, and Leonard Wantchekon for helpful suggestions. I am particularly grateful to Christian Helmers for excellent research assistance during the fieldwork. I thank seminar participants at the NEUDC Conference, BREAD/CEPR Conference, ASA Meetings, APSA Meetings, EEA Congress, University of Chicago, New York University, CSAE Conference, University of Manchester, University of Oxford, and the LSE-Oxford RPC Workshop. The National Electoral Commission of Sao Tome and Principe, represented by its president, José Carlos Barreiros, provided invaluable local support to this research, for which I am most indebted. I am also thankful to CPLP, namely Hélder Lucas and Leonardo Simão, for coordination with their electoral observation mission. A. Assunção, C. Castro, D. Coelho, A. Costa, A. Dias, M. Diogo, E. Lima, H. Mandinga, C. Moreno, A. Penhor, and E. Solé, constituted our team co-members in the experiment conducted: their dedication was crucial for the success of this project. I wish to acknowledge financial support from the Open Society Institute, and the ESRC-funded Global Poverty Research Group. All errors are my responsibility.

${ }^{1}$ Email: pedro.vicente@economics.ox.ac.uk Address: Department of Economics/CSAE, University of Oxford, Manor Road Building, Oxford OX1 3UQ, UK.
} 


\section{Table of Contents}

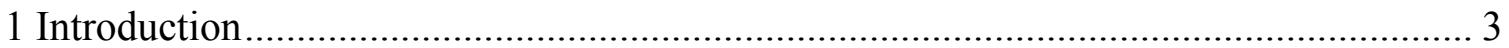

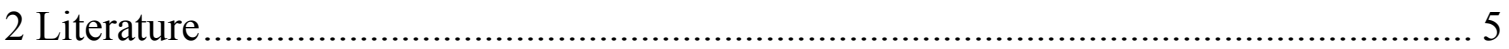

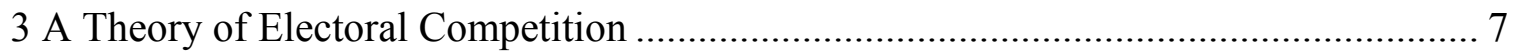

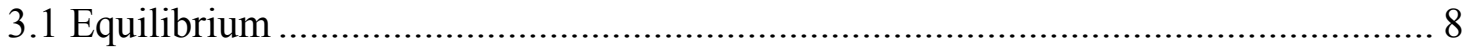

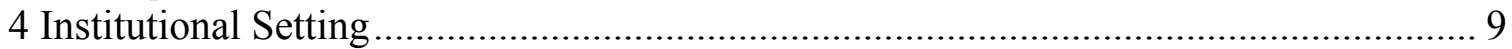

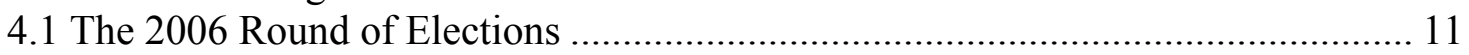

4.2 Validity of Theoretical Setting ........................................................................ 12

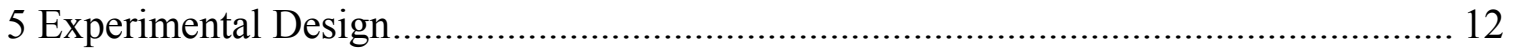

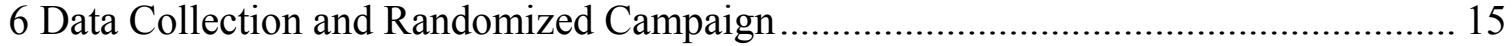

6.1 Survey Sampling Procedure............................................................................ 15

6.2 The Anti-Vote Buying Campaign ....................................................................... 16

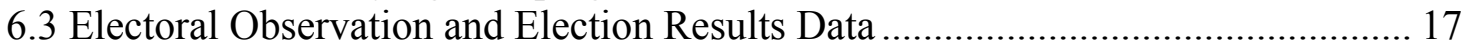

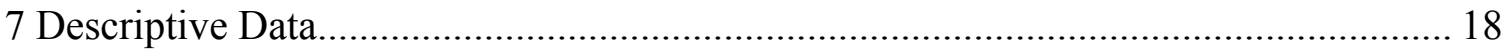

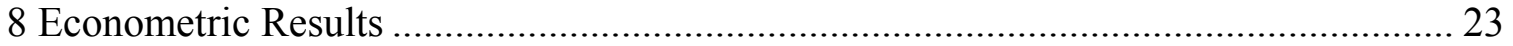

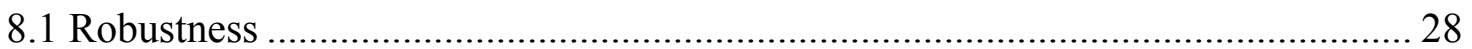

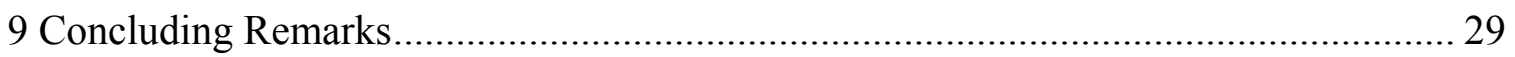

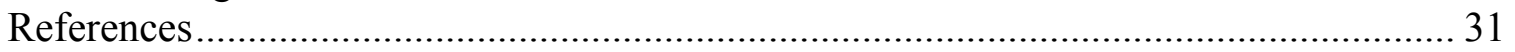

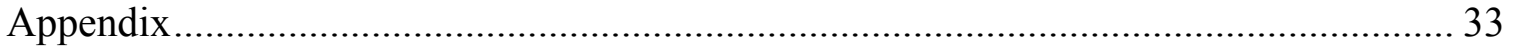

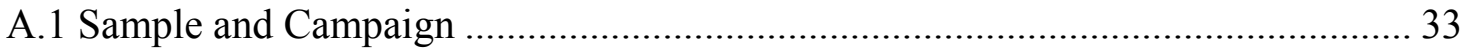

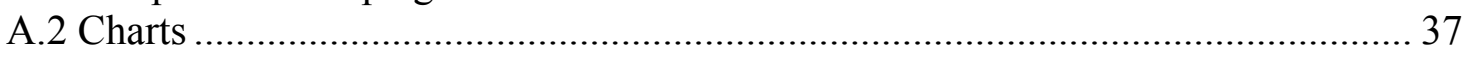

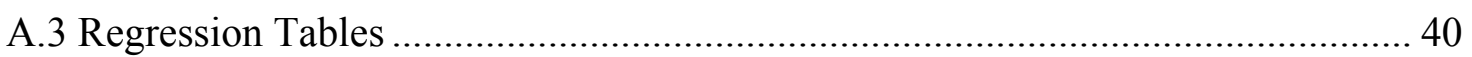


"We do like vote buying. It is essential. That is the only way we have to see anything good coming from the politicians. Anyway, I can vote for whoever I want."

- Anonymous (Sao Tome)

\section{Introduction}

The idea that a few can capture the democratic electoral process of a country has been at the center of political economics from its inception. Pressure groups and lobbying are recognized as essential ingredients to the understanding of modern democracies. In this context the profession tends to rest assured that competition (Becker, 1983) and informed voters (Grossman and Helpman, 1996) keep the outcome close to efficiency and not too biased in favor of the powerful. Privately-funded campaign spending is then the main visible component of an essentially-benign influencing process ${ }^{2}$.

Interested observers are however becoming more alerted to the weaknesses of democratic processes in developing countries. There, competition may be curtailed by credit constraints, and the demand for information may be undermined by voters' lack of education. Vote buying, as a specific form of campaign spending (not associated with meaningful political messages), tends to flourish in these environments, as if it were a substitute for political accountability. Vote buying may therefore be a symptom of poor democratic practice. This would be particularly so if vote buying really is effective in driving the electorate.

Interestingly, blunt vote buying, as the exchange of cash or other goods for votes in forthcoming elections, has in its definition an obvious economic inconsistency. If taken literally, this exchange needs enforcement at the ballot station, i.e. lifting of secret voting! Since this is generally quite a strong requirement in democracies, it is therefore a relevant empirical question to ask whether vote buying efforts are effective in earning votes. This is the main purpose of this paper.

We look at the case of Sao Tome and Principe, a small West African country, where a significant oil discovery happened in the end of the 90s. Earlier work (Vicente, 2006, 2007) found an important increase in corruption after the discovery announcements, where vote buying featured prominently - consistently with the idea that elites see political power as more valuable after the oil news. This finding has been related to an increase in foreign oil-industry related interests (Frynas et al, 2003). According to this perspective, we also view our work paper as contributing to a better understanding of the natural resource curse (Sachs and Warner, 1995; Mehlum et al,

\footnotetext{
${ }^{2}$ This idea is reinforced by Ansolabehere et al (2003), who argue that campaign contributions in the U.S. constitute more a form of political participation and consumption than a form of policy buying.
} 
2006) by showing that vote buying may be a channel to the capture of political power in a newly rich oil developing country.

To reach our research objectives we have undertaken a fully tailored randomized field experiment during the Presidential elections of July 2006 in Sao Tome and Principe. Our design was centered on a leaflet-based, door-to-door campaign against vote buying, sponsored by the National Electoral Commission of the country. Crucially, the locations (census areas) picked up for this campaign were chosen randomly. This intervention was accompanied by pre and post-election household-representative surveys in 50 census areas (out of the total 149 for the country), targeting a panel of 1034 respondents. This corresponds to more than $1 \%$ of the electorate of the country. We contrast pre and post-election perceptions of vote buying (making use of the comparable parliamentary elections of March 2006 for the pre-election questions), as well as voting intentions (before elections) and reported voting (after elections).

We use difference-in-differences -type estimators to derive our main results. We first test whether the campaign was able to change vote buying. This enables us to argue for the existence of exogenous variation in vote buying (on its frequency or effectiveness). This exercise also provides evidence on the ability of an anti-vote buying campaign to undermine those practices, which on its own constitutes important policy information for those interested in fighting for strict accountability-based politics.

In a second stage, informed on the existence of exogenous variation in vote buying, we use the randomized campaign to derive effects of vote buying on voting behavior.

The design of the experiment allowed controlling for measurement biases induced by the treatment upon respondents (on artificially conforming to the message of the campaign). We employ a placebo technique that uses the timing of the treatment together with the time dimension of the baseline questions to identify such biases. We employ a rich set of control variables in deriving our results, stemming not only from the surveys conducted, but also from electoral observation data collected from the main international mission deployed to the presidential elections. The first set includes changes in policy platforms and general information about the candidates (alternative-to-the-campaign causes of changes in voting behavior). The second includes minutes of electoral observation in all locations sampled, gathered in the context of purposely-tailored questionnaires.

We interpret our results in light of a simple model of electoral competition that resembles the context of the Presidential elections of 2006 in Sao Tome and Principe. This is a sequential game where both incumbent and challenger buy votes - the incumbent moves first (consistently with the late and to some extent unanticipated candidacy announcement by the challenger in Sao Tome 
and Principe). We assume the electorate has a fixed distribution of ideology (or innate biases for the candidates). The model mainly predicts that vote buying for both contenders will be targeting voters with low innate biases for the candidates (swing voters). Generally, due to the sequential nature of the setting, in the event of an intervention against vote buying close to the election, it is the challenger who is mostly affected in the power of his vote buying activities.

Consistently with the main prediction of the model, we find that more competitive, swing locations (as given by previous electoral results data) tend to witness more vote buying.

Our analysis shows that the anti-vote buying campaign was effective in terms of diminishing its frequency, but mostly in diminishing its effectiveness (as perceived by the respondents in our panel). This is consistent with the message of the campaign that underlined the need to 'vote in conscience' (more than that of not accepting gifts). We do not observe robust effects of the electoral observers on vote buying.

We also find that perceived vote buying at the location level seems to be inducing higher voter turnout (working as an energizer of the electorate), and that the campaign had a clear and significant effect on increasing changes of votes (from intention before elections to actual voting reported after elections) towards the incumbent, which is consistent with the sequential nature of the setting. We check whether the campaign had an effect at the macro-level election results by exploring effects on per-ballot actual results: we find a consistent sign (favoring the incumbent) but borderline statistical significance.

The remaining of the paper begins by presenting a literature review, the theory we take as the benchmark for the analysis of our experiment, and the actual institutional setting faced in Sao Tome and Principe. We then describe the experimental design and the data collection/randomized campaign fieldwork. Descriptive data on the research questions at stake together with econometric results constitute the following sections. We finally conclude.

\section{Literature}

This research connects to several different strands of literature in political economics and mainlyquantitative political science.

The historical studies of Cox and Kousser (1981) and Cox (1987) on the emergence of the $20^{\text {th }}$ century electoral politics of New York State and England (respectively) provide important insights for the understanding of the process that led to the root original decrease of vote buying in both the US and Britain. The first emphasizes the effects of legal electoral reforms (e.g. secret 
voting) on decreasing electoral corruption and leading to diminished voter turnout ${ }^{3}$. The second underlines the fact that most legal reforms in England (like the Corrupt Practices Act in 1883) actually came after the decline of power in individual MPs (relative to parties), which is seen to be associated with the bulk of the change in electoral behavior (from purely patron-client politics). Both studies provide an important comparative evolutionary perspective that helps framing the determinants of vote buying.

The theoretical literature on vote buying sheds light on the characteristics of equilibrium outcomes, namely on their welfare implications. Importantly, vote buying has traditionally been seen as embedding non-existence of equilibrium in majoritarian settings (e.g. Weiss, 1988), as the only valuable vote is the marginal one. Very different conclusions on efficiency improvements associated with a market for votes have been presented by different authors under specific vote buying settings (e.g. Wess, 1988; Philipson and Snyder, 1996; Dekel et al, 2006).

This paper directly relates with empirical work on clientelism and vote buying in developing countries. Namely, experimental work by Wantchekon (2003) on clientelism (votes in exchange for future politicians' favors, when elected), performed in Benin by randomly drawing locations for clientelistic and public policy campaign messages, showed that clientelism works better for regional and incumbent candidates and is less well viewed by women, who are more attracted to the public-policy type of campaigning. Brusco et al (2004) present comprehensive survey-based non-experimental work on vote buying in Argentina, reaching reports that are consistent with effectiveness of vote buying when vote buying transactions are enforceable. We build on these methods, by combining survey (pre and post-election) and experimental methods to directly target the consequences of vote buying.

The extensive literature on empirical effectiveness of campaign spending, which is centered on the US, is also closely connected with this paper, although we focus on a very specific kind of campaign spending. This literature began with Jacobson (1978), who presented evidence for Congressional elections that challengers have clearly higher returns to campaign spending than incumbents. However, these results were based on OLS regressions, which are generally tainted with endogeneity bias (this is clear for incumbents, who are seen as responding with higher campaign spending when faced with stronger threats). This led to a far-reaching debate that included somewhat different results: while Jacobson $(1985,1990)$ and Abramowitz (1988) still find the same pattern for Congressional and Senate elections (respectively), Green and Krasno

\footnotetext{
${ }^{3}$ Interestingly it also documents perverse effects of vote buying on decreasing turnout, e.g. bribing opponent's voters to stay at home on election day, which is a present-day phenomenon we report on in the empirical part of this paper.
} 
(1988), Levitt (1994), Gerber (1998), and Erikson and Palfrey (2000) find that challenger and incumbent have similar voting returns from campaign spending, typically close to zero. Note that most of these studies employ methods other than OLS, namely using instrumental variables and panel data to overcome the referred technical difficulty. Recently, Gerber (2004) recovers the initial Jacobson pattern by analyzing several experimental settings (where exogeneity of campaign spending is ensured by construction) $)^{4}$. These stem from randomization of direct mailbased campaign in a number of different elections in the US (mayoral, state assembly, state legislature, Congressional primary, and Congressional general elections $)^{5}$.

It is indeed the prominent pattern of this campaign spending literature (that challenger spending is more effective than the incumbent's) that we find in our experiment on vote buying, which lends some consistency to the finding, while extending it to a more specific kind of campaign spending and to a dramatically different, developing country context.

\section{A Theory of Electoral Competition}

We propose a simple model in the spirit of the classic Colonel Blotto game ${ }^{6}$ and of Dixit and Londregan's (1996) model of redistributive politics. Differently however, we assume a sequential game. We consider electoral competition between two candidates, $I$ (for Incumbent) and $C$ (for Challenger). From the point of view of the voter, the two can differ in terms of fundamental values (for simplicity, 'ideology') or in terms of cash transfers (vote buying propositions). Ideologies are assumed to be fixed for each candidate.

The voters are modeled as a continuum (from 0 to 1 ) and distinguished by their degree of ideological affinity to one candidate or the other. We define $X$ as the ideological preference for candidate $I$ over $C$ (without loss of generality). We assume for simplicity that this ideological attachment is distributed uniformly among the voters in the interval $[-1 / 2,1 / 2]$. We postulate that the voters also care for material benefits $Y$. We therefore assume that a voter $i$ will vote for $C$ if

\footnotetext{
${ }^{4}$ See Gerber and Green (2000) for an additional experimental exercise related to non-partisan voter turnout.

${ }^{5}$ Note that Gerber (2004) also introduces a theoretical exploration to explain the challenger-advantage found empirically: by assuming candidates only care about winning the elections (not about their share of votes), one can find that an incumbent may want to insure himself against the worst case scenario by targeting his base, which yields low spending returns on average, but an effective winning boost in case he cannot effectively reach the larger electorate. In the model below we opt to maintain the more general assumption that candidates maximize their shares of votes. In fact Gerber's model seems to be rejected in our data provided we will find ahead incumbent and challenger seem to be pursuing similar targeting strategies.

${ }^{6}$ See Roberson (2006), for a complete characterization of the classical game.
} 


$$
Y_{i C}-Y_{i I} \geq X_{i}
$$

Note that in this model each candidate only cares about its percentage of vote $P_{j}(j=I, C)$. Candidates are assumed to take as given the budgets $B_{j}$ they have available to spend in the elections (for simplicity these can only be spent buying voters).

We assume a complete information game where candidate I moves first by setting $Y_{I}$, with candidate $\mathrm{C}$ moving after that by choosing $Y_{C}$. Voters vote in a third stage.

Note that this model assumes perfect enforcement of the voter-candidate transaction, i.e. effectiveness of vote buying. This can be ensured by a number of mechanisms ${ }^{7}$, which although explored in our empirical section, are not the main focus of this paper. For simplicity, we therefore opt to leave them out of this theoretical formalization.

\subsection{Equilibrium}

The above simple model setup implies that candidates will spend all their budgets in equilibrium. The main question is how they are going to spend them.

We also know that each candidate has a relative advantage with different voters, i.e. a voter with an ideological bias in favor of candidate $I$ will require more cash to vote for $C$ than a candidate with an ideological bias in favor of $C$.

Solving this game by backward induction and given the obvious (described above) voter behavior, candidate $C$ will use its budget efficiently by spending $X_{i}+Y_{i I}$ on a set of voters such that the budget limit is fully employed but not exceeded, i.e. $\int_{0}^{1} Y_{i j} d i=B_{j}(j=I, C)$. Given the objective of maximizing her own percentage of votes $P_{C}$, Candidate $C$ will choose the 'cheapest' voters, i.e. she will bribe those voters for whom $X_{i}+Y_{i I}$ is positive and smallest.

Candidate $I$, given the described behavior by $C$ and given that all voters count the same to her objective, will find wisest to have her lowest-enthusiasm supporters equally protected against vote buying by $C$. However this may mean buying many ideological supporters of candidate $C$ or protecting many own ideological supporters (cases $a$ and $b$ in Figure 1 below) from $C$ 's vote buying. We find that that a combination of both (the exact middle term) maximizes voting for $I$

\footnotetext{
${ }^{7}$ These include techniques to lift secret voting (for instance involving intimidation), and self-enforcement. Self-enforcement mechanisms may include viewing candidates' bribes as signaling for future favors when elected (in this sense vote buying can be close to clientelism), or simply good policies (Prat et al, 2006, explore this mechanism for general campaign spending in the U.S.), but may also encompass feelings of moral obligation. Empirical identification of these different mechanisms is patently non-trivial.
} 
for the same $C$ 's budget (Figure 2) - provided it maximizes the area inside the bottom-left quadrant (implying the challenger will be obliged to spend more money for less voters). Note that the examples below provide constant budgets, given by the area of the blank triangles in both figures for $I$ and by the light colored rectangle in Figure 2 for $C$.

We can therefore conclude that in a setting with both ideology and vote buying as electoral driving forces, both candidates will want to buy the votes of swing/most undecided voters (in the view of ideology). This is verified with our data below. Furthermore, given the sequential nature of this game, i.e. in the context where an incumbent has the opportunity to buy votes during her mandate, we should be able to observe mainly the challenger being effective during the stages just before the election takes place (electoral campaign). This is the main proposition we take to the data, through the analysis of our experiment.

Figure 1

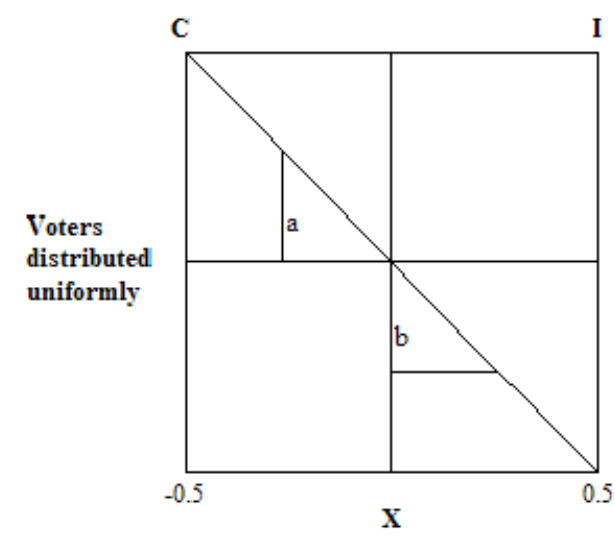

Figure 2

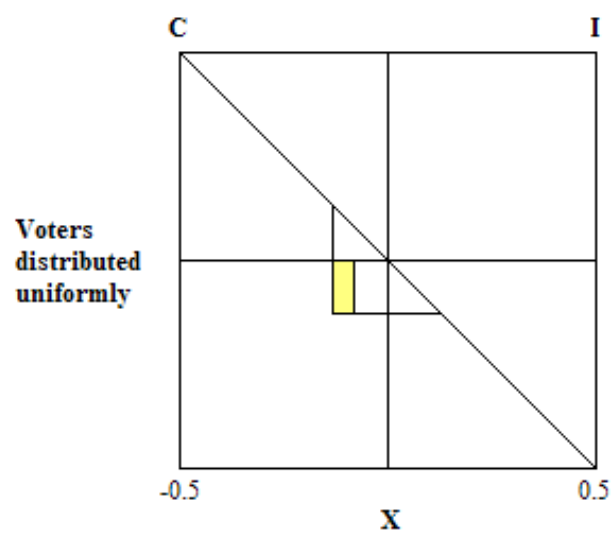

\section{Institutional Setting}

Sao Tome and Principe (STP) is a two-island West African country with 148,000 inhabitants ${ }^{8}$ and one of the poorest countries in the world (USD 1200 in $2003^{9}$, ranking 207 out of 233 countries). After almost five centuries of Portuguese colonization, it achieved independence in 1975. As was common trend in Lusophone Africa, its first regime was socialist, with MLSTP (Liberation Movement of Sao Tome and Principe), the independence movement taking on the role of ruling

\footnotetext{
${ }^{8}$ World Development Indicators, World Bank.

${ }^{9}$ CIA Factbook, 2006.
} 
party. In the late eighties, the international context together with a steep decline in cocoa prices (STP's main export) led the ruling elite to start a democratization process that culminated in the first free elections in $1991^{10}$. STP was constituted as a semi-presidentialist democratic regime, with most executive/legislative powers attributed to the National Assembly, from which the government emerges, but important arbitrage and defense/foreign affairs authority given to the president. Contrary to most first multi-party elections in Africa, the incumbent party MLSTP and president Pinto da Costa (1975-1991) were ousted in $1991^{11}$.

Post-democratization politics in STP have been dominated by MLSTP/Pinto da Costa and alternative prominent 'political families'. These have mainly centered around Miguel Trovoada (STP president in the period 1991-2001), who founded ADI (Independent Democratic Alliance) in 1993, and Fradique de Menezes (STP president in the period 2001-present), who founded MDFM (Democratic Movement for Empowered Reform) in $2001^{12}$.

Importantly, interesting news was brought to this country in the late nineties: significant oil reserves were discovered off its coast. This fact has been bringing considerable international attention to STP. The process of oil exploration has itself not been free from problems: these ranged from clearly damaging (to STP) initial contracts for soundings and exploration ${ }^{13}$ to numerous allegations of corruption within the STP political elite. Although production is not expected to start before 2011, auctions were opened and concession blocks have been allocated to oil companies from 2003. As an illustration of the size of this shock for STP, bidding for the 2003 round of auctions represented $240 \%$ of the GDP of the country in that year.

In this scenario, the STP government has been seen to be facing strong pressures from international players related with the oil sector. This has been pointed by some sources - Frynas et al, 2004, Vicente, 2006 - to be linked to a steep increase in vote buying, starting with the 2001/2002 round of elections and continuing with the 2006 parliamentary and presidential elections. This is the interesting context in which we propose to study the consequences of vote buying.

\footnotetext{
${ }^{10}$ See Seibert (2006) for a thorough historical coverage of this period.

${ }^{11}$ After that, MLSTP went back to government in 1994 (to be ousted only in March 2006 as the second most voted party) but never gained the presidency again.

${ }^{12}$ ADI was the second most voted party in 1994 and 1998, third in 2002 (in coalition Ue-Kedadji) and 2006. MDFM allied with PCD (Democratic Convergence Party), the winning party in 1991 (then still with the support of Miguel Trovoada) which then took on third place for the remaining of the nineties. MDFMPCD was second in 2002 and won the 2006 parliamentary elections.

${ }^{13}$ Namely, in 1997, for USD 5m the STP government signed a controversial exclusive deal with ERHC (Environmental Remediation Holding Corporation), an obscure US-based oil company, which managed to secure a percentage of future exploration revenues as well as preferential rights in the future allocation of blocks. The initial contract was however renegotiated as a response to pressures by international institutions.
} 


\subsection{The 2006 Round of Elections}

In 2006 both parliamentary and presidential elections took place in STP. The first took place in March, with some repetitions due to population boycotts in some constituencies taking place in April. The presidential elections took place on July $30^{\text {th }}$. As described above, mainly due to the expected oil boom but also due to a reform attributing more powers to the government, stakes were considered to be very high for both elections but particularly for the parliamentary elections. MDFM-PCD gained control of the parliament with a clear victory over MLSTP (36.8 vs. 29.5\%); ADI came third with $20 \%$; interestingly, a new party Novo Rumo (New Way) won a parliament seat making a campaign out of an anti-vote buying platform. International observers considered these elections to have respected international standards but warned/reported about frequent vote buying.

The presidential elections featured Fradique de Menezes (FM), MDFM-PCD driving force, running for re-election. We argue that an interesting setting, prone to experimental work, formed for these elections. Although FM announced formally that he was running for re-election only close to the elections in June, it was well-known he would do so by the final part of his mandate. What was not clear at all, still in the beginning of June, was who would run against him, representing MLSTP and/or ADI. This was formally known later that month: Patrice Trovoada (PT), son of Miguel Trovoada, former minister with responsibilities in the oil-related deals and member of ADI, a young and rising political figure, managed to get MLSTP support, apart from the natural ADI sponsorship (i.e. both major opposition parties) ${ }^{14}$. PT then took on a top-layer political role for the first time (as head of opposition). Since our analysis starts in the beginning of July, we are confident that our experimental field activities are contemporaneous or precedent to the whole campaign process by PT (including the bulk of his vote buying).

FM won comfortably with $60.6 \%$ against $38.8 \%$ by $\mathrm{PT}^{15}$. These results yielding a clear difference were well accepted not only by the candidates but also by international observers, who

\footnotetext{
${ }^{14}$ Many observers took this unusual alliance (in the STP context) as a sign that financial liquidity by the Trovoada family was a key factor in the face of a broken MLSTP, which had spent all its resources in the parliamentary elections and saw diminished financial international support by long-standing allies like Angola's MPLA.

${ }^{15}$ There was a third, independent, candidate (Nilo Guimarães) who won $0.6 \%$ of votes. Given this outcome and the negligible political relevance of this candidacy, we do not mention this candidate in our analysis.
} 
nevertheless repeated vote buying-related concerns ${ }^{16}$. Note that the main contingent of international observers was deployed by CPLP (Portuguese-Speaking Community of Countries), including representatives from Angola, Brazil, Cape Verde, East-Timor, Guinea-Bissau, Mozambique, and Portugal ${ }^{17}$. In addition to our survey backbone data, we use in this work data purposely collected in STP from these CPLP observers.

\subsection{Validity of Theoretical Setting}

From the above-described institutional context of the 2006 presidential elections, we can now identify the key assumptions of our theoretical model. First, the existence of a clearly defined incumbent who has a first mover condition - FM is in fact the most powerful political personality in the country since 2001, having personally faced in practice three elections before the July 2006 suffrage, with a known history of vote buying -, and the short-notice challenger candidacy of PT, a younger and less prominent politician. This implied a 'last-minute' window for vote buying by the PT candidacy, which strengthens the sequential nature of our game. Second, although clear ideological positioning is to a large extent absent in the politics of STP, there are still strong biases pro and against each candidate (stemming from historical paths, and general 'attachment' to political families) - our theoretical 'ideology' variable attempts to capture that component of the politics of STP, helpful in determining the pattern of vote buying.

\section{Experimental Design}

The basic structure of our experimental design is provided by a panel of 1034 individuals, interviewed just before the bulk of the formal electoral campaign in July, and just after the election day in August ${ }^{18}$. These individuals were spread over 50 representative census areas. A campaign was conducted in 40 of these areas during the pre-election survey. These treatment areas were chosen randomly - this selection procedure enables contrasting comparable, homogeneous treatment and control areas. This campaign was publicly sponsored by the National Electoral Commission and focused on the issue of vote buying, namely on its illegal and

\footnotetext{
${ }^{16}$ CPLP (Portuguese-Speaking Community of Countries), Relatório da Missão de Observação Eleitoral da Comunidade dos Paises de Língua Portuguesa às Eleições Presidenciais de São Tomé e Príncipe de 30 de Julho de 2006.

${ }^{17}$ The remaining observers were deployed locally by foreign diplomatic representations.

${ }^{18}$ Both surveys were in the field during 2 to 3 weeks.
} 
democracy-harming nature. Verbally, the importance of 'voting in conscience' - by not letting vote buying affect voting choices - was underlined.

Our basic data design comes from survey questions on vote buying perceptions asked in the preelection survey about the parliamentary elections of March (our reference period), and asked in the post-election survey about the presidential elections of July. Voting behavior intentions (on the presidential elections) in the pre-election survey are also compared with voting behavior reported in the post-election survey.

In our design we also address what we denominate 'conformity bias'. This is a bias that may be present in any experiment where the treatment works by trying to change people's opinion (i.e. convince them to adopt a certain idea): subjects may be induced to report adherence to the ideas of the treatment, even if they truly do not feel so. This is because treated subjects, unlike control subjects, are informed about the content of the treatment. In our case, in the post-intervention survey, respondents may be induced to 'conform' artificially to the ideas conveyed in the campaign, which would then bias the effects of the campaign ${ }^{19}$. We address this problem by rather conservatively having the campaign, i.e. leaflet distribution and explanation, positioned before the relevant questions on vote buying perceptions in the pre-election survey (relative to the March parliamentary elections). In that fashion any existing conformity bias would be present in both surveys (through the use of a 'time placebo' in the pre-election survey), enabling a better measurement of the difference on perceptions, our target with this design. We feel this is a key improvement on standard experimental methodology regarding non-incentive compatible 'adoption' treatments.

This research setting enables the use of a difference-in-differences design, by comparing variables before and after the anti-vote buying campaign, across treated and control areas.

The overall design can be seen in schematic form in the following figure.

In a first stage, we hope to be able to evaluate the effects of the anti-vote buying campaign on vote buying. This is interesting per se, but also enables the identification of the ability of the campaign to drive behavior, which is useful for the remaining of the main exercise of this paper. This can be written as

$$
\Delta V B_{i, l}=a+b X_{i}+c Y_{l}+d T_{l}+\varepsilon_{i, l}
$$

\footnotetext{
${ }^{19}$ Note that the fact that our field team was involved not only in the surveys but also in the actual randomized campaign (under the sponsorship of the National Electoral Commission) may potentially increase this bias.
} 
Figure 3: Vote Buying Experiment in Sao Tome and Principe

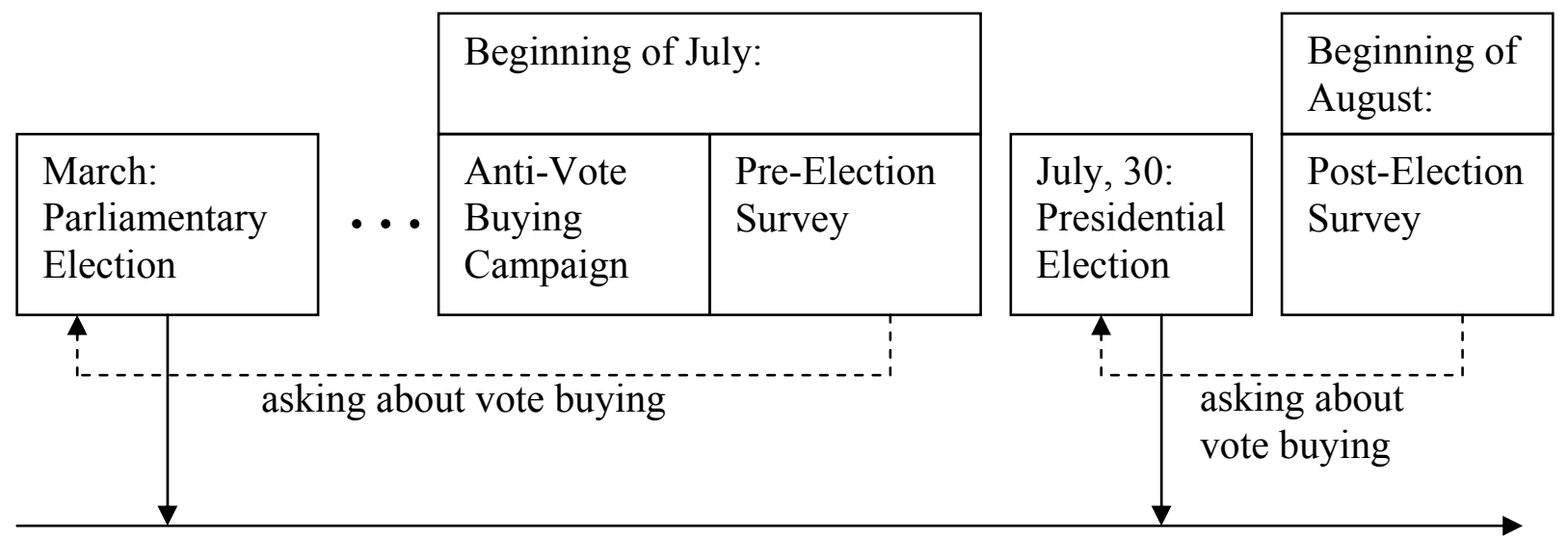

Time Line

for individual $i$ and location $l$, where the dependent variable is change in vote buying (comparing perceptions about the parliamentary and presidential elections), $X$ is vector of individual controls, $Y$ is a vector of location controls, and $T$ is a dummy variable taking value 1 in treated areas.

In the second stage, given the identification of significant effects of the campaign in diminishing the power (frequency or effectiveness) of vote buying (we are then safe in assuming there is exogenous variation in vote buying), we hope to be able to identify the effect of vote buying on electoral behavior. This is by using a regression of the form:

$$
\Delta V_{i, l}=e+f X_{i}+g Y_{l}+h T_{l}+\varepsilon_{i, l}
$$

where the dependent variable is change in voting behavior (intended vs. actual reported) for the presidential elections.

In the end of the paper we also attempt identification of the effect of the campaign on voting behavior by running a regression on actual per location (ballot station) voting outcome ${ }^{20}$ :

$$
V_{l}=m+n Y_{l}+o T_{l}+\varepsilon_{l}
$$

Any significant effects using this specification would mean the campaign was powerful enough to change electoral results at the country (macro) level.

\footnotetext{
${ }^{20}$ Note that we opt not to show this specification using the time dimension. This is provided there is no definitive way of comparing specific results of parliamentary and presidential elections of 2006, and provided the previous presidential elections happened long before (5 years earlier).
} 
We use several important controls when deriving our effects of interest. In addition to demographic variables and location characteristics, we employ controls for: information gathered about the candidates (about candidacies per se, surprises during the electoral campaign, and policy platforms perceived for the candidates; we also use proxies for individual participation in the electoral campaign); the electoral observation mission of CPLP (minutes spent at each location) - electoral observation is widely seen as the most important institutionalized source of enforcement of good electoral behavior in countries like STP; survey-based measures of psychological consistency of respondents (e.g. tendency not to report change in opinion even if it took place).

\section{Data Collection and Randomized Campaign}

The randomized field experiment was conducted by a team of 11 local interviewers/campaigners. This team was fully recruited and trained by the author and a research assistant. The author was in the field at all times of the conduction of this experiment. Each interviewer had a total of 10 hours of training in small groups of 2-3 people. Training included lectures on the content/objectives of the experiment (with special attention to the questionnaire and the script for the campaign), individual answering of the questionnaire, and individual piloting of both the questionnaire and campaign script.

\subsection{Survey Sampling Procedure}

Our sample consisted of 50 census areas (these can be seen in the maps of the Appendix). These locations were chosen randomly within the 149 census areas of the country (i.e. we were able to reach one third of the country in this experiment), weighting by the number of households (using the 2001 census data from the National Statistics Office). Households within a census area were chosen randomly using standard techniques like selecting the $\mathrm{n}^{\text {th }}$ house (depending on the number of households in the census area), with second visits tried in the same day. The conditions for sampling a respondent within a household were: aging 18 years or more, and criteria related with residence in the country.

Despite the fact that this is a standard sampling procedure, we still faced imperfections to random sampling of households. These stem from differences in the number of interviews across census areas and from non-respondents (including panel drops). To address this problem, we use weighted data in the regressions we show ahead. Data weighting accounts for both problems (it is 
made possible since we collected information from non-respondents: gender, approximate age, schooling, and income), and is used uniquely for consistency with the sampling approach: differences to un-weighted data are negligible throughout.

We were able to gather 1275 observations in the pre-election survey and 1034 observations in the post-election survey. This represented an $81 \%$ rate of re-surveying in the panel ${ }^{21}$, with a minimum of $61 \%$ and a maximum of $100 \%$ across census areas in our sample. Table A1 in the Appendix has all details per census area.

The survey instruments were tailored for this experiment ${ }^{22}$. The pre-election questionnaire featured demographic and psychology questions followed by the questions on vote buying (mainly about the parliamentary elections of March 2006) and individual political positioning. The post-election survey only included questions on perceptions about the presidential elections (mainly on vote buying, but also including some items on intimidation and electoral observation) and on individual political positioning in those elections.

\subsection{The Anti-Vote Buying Campaign}

The anti-vote buying campaign was implemented in 40 out of the 50 locations sampled for the surveys. This choice was made randomly by the author. The campaign was sponsored by the National Electoral Commission, and this endorsement was systematically mentioned during all times of the conduction of the campaign.

The campaign consisted of the distribution of a leaflet (see Appendix), and the verbal explanation of its message. The leaflet was mainly legalistic, conveying the message that vote buying is illegal under the Sao-Tomean law. Its main slogan was 'Do not let your conscience have a 'banho', where 'banho' refers to vote buying (meaning literally 'bath' or 'shower' in Portuguese). The leaflet also included an allusive drawing which enabled reaching the illiterate population.

Even though this was the written message, from early piloting it was clear that vote buying is a popular phenomenon for the impoverished STP population. In Chart A1 in Appendix it is shown how respondents perceived vote buying before the campaign: although many associated it primarily with a bad practice on moral or legal grounds (not meaning many of these respondents

\footnotetext{
${ }^{21}$ We tried to find all lost pre-election respondents during the post-election survey. A thorough tracking method, implemented during the pre-election survey, including questions on individual identification, address descriptions, and the representation of all houses surveyed in the census area maps supplied by the National Statistics Office, allowed the successful identification of all houses in the post-election survey. However, refusals, empty houses, and respondents' absence, led to the above dropping rate.

${ }^{22}$ Both pre and post-election instruments are available upon request to the author.
} 
are not vote buying supporters), there is a noteworthy section who views it primarily in a weakly positive manner $(22 \%)$. This led to including in the campaign's verbal approach the idea that 'accepting gifts is not important, what is important for democracy is not letting those gifts influence voting'. Despite the fact that the legalistic view is being taken less strictly with this statement, this is still fully consistent with the main research questions in our experiment (on the impact of less effective vote buying on actual voting behavior).

The campaign was able to deliver 10,000 leaflets in treated locations (on average 1 leaflet per household). The distribution of leaflets was done during the period of the pre-election survey. More specifically, all respondents were given the leaflet before the questions on vote buying (to diminish the possibility that the above-referred conformity bias contaminates the differences we aim to identify); neighbors of respondents (primarily) were also targeted in treated areas. This means the campaign although implemented at the location level, was centered around our panel of respondents.

\subsection{Electoral Observation and Election Results Data}

We were able to submit a questionnaire to all 16 international observers of CPLP. This submission was done ex-ante, at the beginning of their week-long electoral observation mission.

In the questionnaire, each location visited was evaluated by each observer. We collected data on the reason for choosing to visit the location ${ }^{23}$, on the time spent in the location, and quantification of electoral problems in the location.

Ex-post, 147 observations were achieved in 175 out of the total 235 (75\%) ballot locations of the country. This meant the electoral observation mission was very comprehensive in terms of geographical coverage: it visited all 7 districts, with the same weight given to each district, i.e. two specialized observers. Note that these data (and, in fact, the whole electoral observation mission) mainly concern the election day $(82 \%)^{24}$.

From the data on selection rules, we reach the conclusion that there is an endogeneity component in the observer geographical deployment. Although 39\% of the locations were seen as chosen on purely random terms, $23 \%$ as a function of population/number of voters, and $23 \%$ as locations

\footnotetext{
${ }^{23}$ The mission did not commit ex-ante to randomize the distribution of observers, although it did not rule out that locations would be chosen randomly ex-post.

${ }^{24}$ This is consistent with the data from the post-election survey (within respondents having witnessed the presence of observers, representing $31 \%$ of the sample, $72 \%$ report that only on the election day the observers were active). This is likely to be the reason why survey respondents consider electoral observers to be most effective in fighting ballot fraud - average 5.1 on a scale from 1 to 7 (most effective); vote buying comes after electoral intimidation with average 4.3 .
} 
'on the way' to other locations (mainly random), there were $14 \%$ of the visits reported to be due to unstable past, reported problems or protests. The fact that more populous areas seemed from these numbers to have benefited from a stronger observation effort is the basis of the use ahead of the number of registered voters in each location as an instrument for electoral observation.

Finally, we also use data provided by the National Electoral Commission on per ballot station results and voter registration in both parliamentary and presidential elections.

\section{Descriptive Data}

In this section we provide a description of main data findings, in order to motivate the specific econometric results we will show in the following section.

We first analyze the data on vote buying. Vote buying was mainly referred to in our instruments using the word 'banho' - this concept includes not only cash received from candidacies, but also individual (e.g. food, construction materials) or collective gifts (e.g. satellite dishes). Although we use mainly perceptions of vote buying in the respondents' neighborhood or village, we have also asked about vote buying offers to personal liaisons of surveyed subjects. We show in Chart 1 what the difference between these two measures was (66\% vs. 38\%). Most probably this large difference is partially due to the immoral/illegal notions associated with vote buying practices (what precluded us from asking about personal direct experiences with vote buying). We have also asked the respondents who reported vote buying offers faced by personal liaisons whether those offers were accepted: almost all reported some degree of acceptance (in 90\% of offers). This is evidence in support of a steady 'supply of votes' - whoever was asked to sell his/her vote, generally yields, even if that does not really correspond to different voting behavior. We revisit this hypothesis when discussing the effects of the campaign.

With respect to the enforcement process of vote buying transactions, we have asked about known techniques used by buyers of votes to ensure the agreed voting action does (or does not) happen: identity card sale (avoiding contender's supporters to vote), ballot paper photos and ballot paper substitution $^{25}$, and pure intimidation. However, we find that the above techniques had quite limited use: as a percentage of all respondents reporting offers to personal liaisons, only $14 \%$ referred the use of these techniques. Intimidation was reported to be more frequently witnessed (though an association with vote buying was not sought when asking): even so, only $11 \%$ of the

\footnotetext{
${ }^{25}$ Several reports on the parliamentary elections included references to the use of: cell phones with camera devices (supplied by vote buyers) in the ballot stations to take photographs of the filled ballot paper by 'bought' voters; exchange of pre-filled ballot paper by real, handed in the ballot station, blank ballot paper. Both photos and blank real ballot paper serve as proof of agreed voting action after the election.
} 
whole sample did report some experience with intimidation of personal liaisons. This is consistent with the idea that self-enforcement may be the main mechanism by which vote buying works in STP.

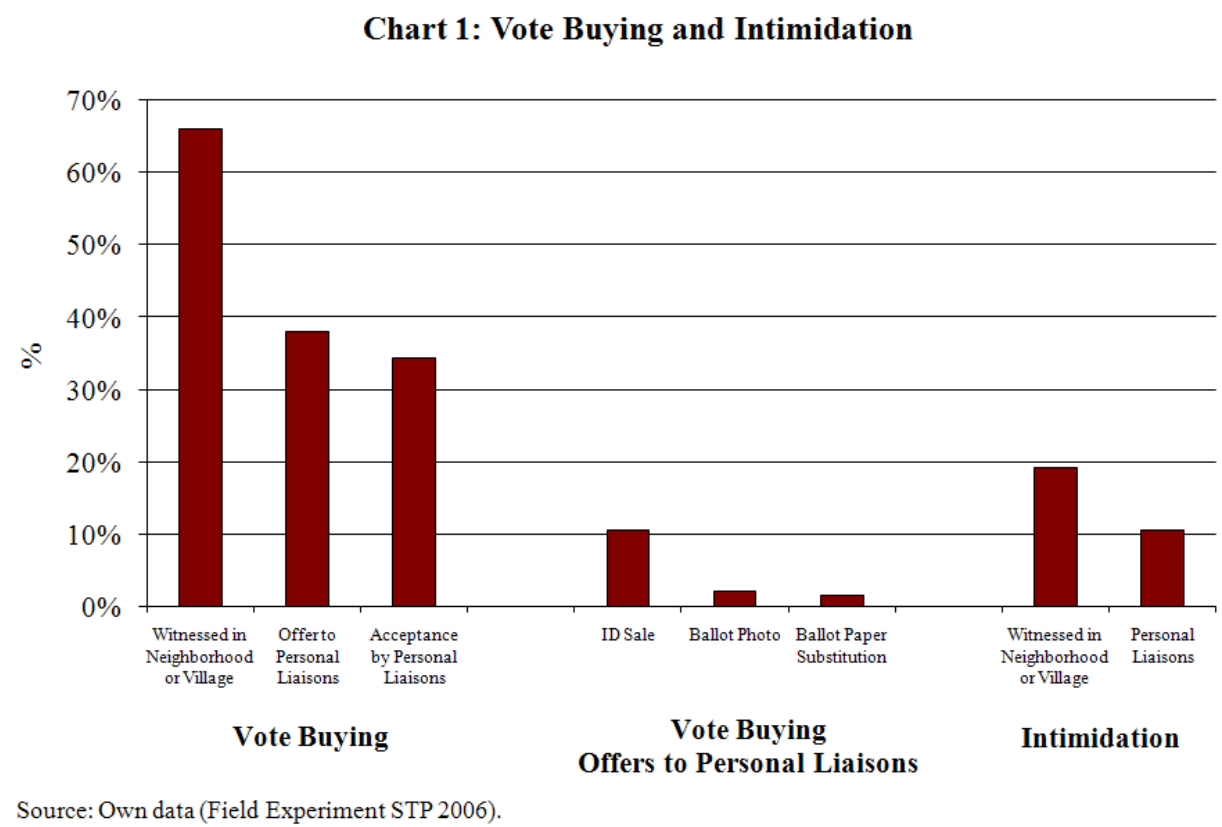

We have also asked our panel about the price of a vote (a 'banho') in the respondent's neighborhood or village, both in the parliamentary (before-survey) and presidential (after-survey) elections. This referred to cash received to vote for the 'buying' candidacy. The next chart shows our findings (averages per district, in all districts).

We found median prices reported (only by respondents stating they witnessed vote buying in their neighborhood or village) to be 7.1 and 4.2 USD in the parliamentary and presidential elections respectively - these are high prices for a country that makes only 100 USD per capita a month. We have also found, consistently with the differential power of the Parliament and the President, that parliamentary elections seem to be more valuable. The fact that the capital district (AG) and the second city (Trindade) district (MZ) have very high prices for the parliamentary elections may be explained (as is argued more specifically in the regressions of the next section) with the idea that the most influential voters of the country (not only for their districts but also for the whole country) are based in those districts. 
In terms of witnessed frequency of vote buying, the same differential pattern arises (parliamentary vs. presidential elections). This can be seen in Chart 3, where we show the actual distribution on the 1 to 7 (extremely frequent) scale used in the instrument ${ }^{26}$.

Chart 2: Prices of Votes

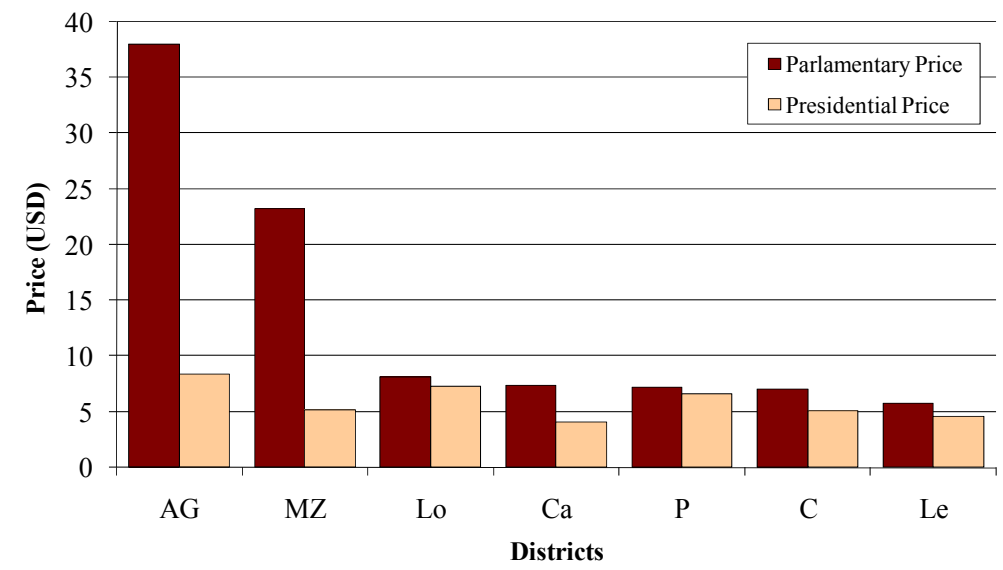

Source: Own data (Field Experiment STP 2006).

Chart 3: Vote Buying in the 2006 Political Campaigns in STP

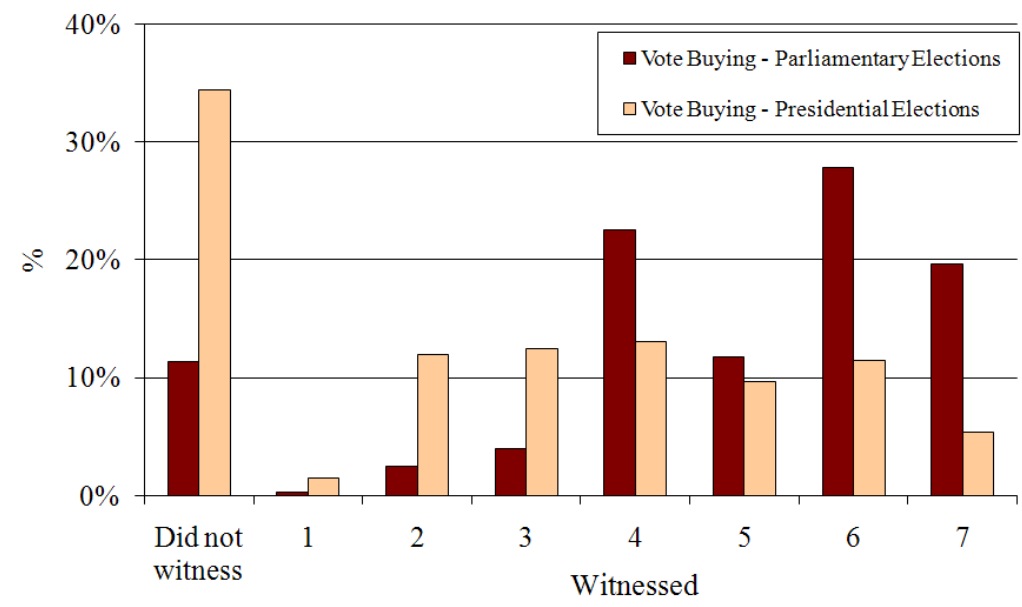

Source: Own data (Field Experiment STP 2006).

Interestingly, respondents do report for the period of the electoral campaign that both candidates were active buying votes in their neighborhood or village. This can be seen in Chart A2 in

\footnotetext{
${ }^{26}$ Note that all subjective scales used in our instrument had 7 points. All were referred to using adjectives (numbers were never used) in a step-wise manner (first on a 3-point scale: in this example, frequent, more or less, not frequent; then depending on the side chosen by the respondent, either frequent or not frequent, a further different 3-point sub scale was used. We are then confident the scales used have been perceived linearly by surveyed subjects.
} 
Appendix, where close to $90 \%$ of respondents witnessing vote buying in their neighborhood or village, report the presence of both candidates ${ }^{27}$.

Our two main research questions regard the effect of the campaign on the vote buying differences across the two elections, and the effect of the campaign on voting behavior (changes between intended and realized behavior).

Chart 4 displays differences in perceived vote buying for treated and control locations. The four questions used are on: the frequency of vote buying transactions witnessed, the perception of influence of vote buying on actual voting behavior in the neighborhood or village of the respondent, and the perception of actual 'voting in conscience' in the neighborhood or village of the respondent (to a certain extent this constitutes the positive counterpart for the second question), the price of votes in the neighborhood or village of the respondent. We can see that the first three effects seem to point to an impact of the campaign in decreasing vote buying or its effectiveness, though smaller in terms of pure frequency of vote buying. Regarding price an effect on decreasing it is observed - this, together with the decrease in frequency, is consistent with an induced change in the demand for votes (in conjunction with a steady supply by poverty-ridden voters, already lightly proposed above).

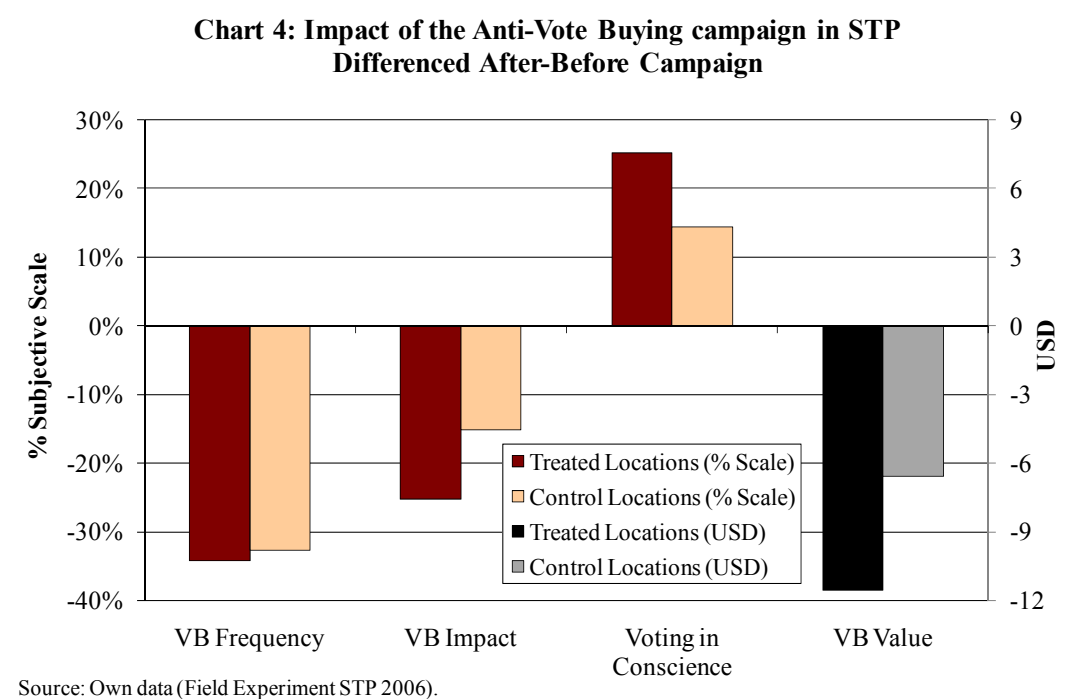

We also show that, consistently with our model, just looking at averages across treatment and control locations, a larger percentage of the respondents who change from voting intention to

\footnotetext{
${ }^{27}$ This fact comes in support of a randomized campaign that is not seen as something against a specific candidate, which helps in the interpretation of the main mechanism of action in this paper.
} 
actual reported choice state they changed towards the incumbent in treatment areas relative to control locations. This is displayed in Chart 5 below.

Importantly, we control for this result in the regressions of the next section by using data on changes of information (held by respondents): not only on strict knowledge about the existence of the candidacies (see Chart A3 in Appendix), but also on own (respondents') and perceived candidates' priorities on policy platforms. Regarding the latter, we asked all surveyed subjects to name the two most important policy concerns by each candidate and for themselves, both in the pre- and post-election questionnaires. These are displayed in Chart A4 in Appendix. First, there is a build-up in the knowledge about the existence of the candidacy of the challenger. We can also see that, although the overall pattern is relatively stable across both surveys, there are some interesting changes in perceptions about policies supported by politicians during the last weeks before elections: namely there is a shift from health, education, oil and corruption, towards jobs, roads, water and electricity (topics targeting the short run). For respondents though, health and education still gain adherence during that period.

Chart 5: \% Changes towards the Incumbent in Vote Reporting

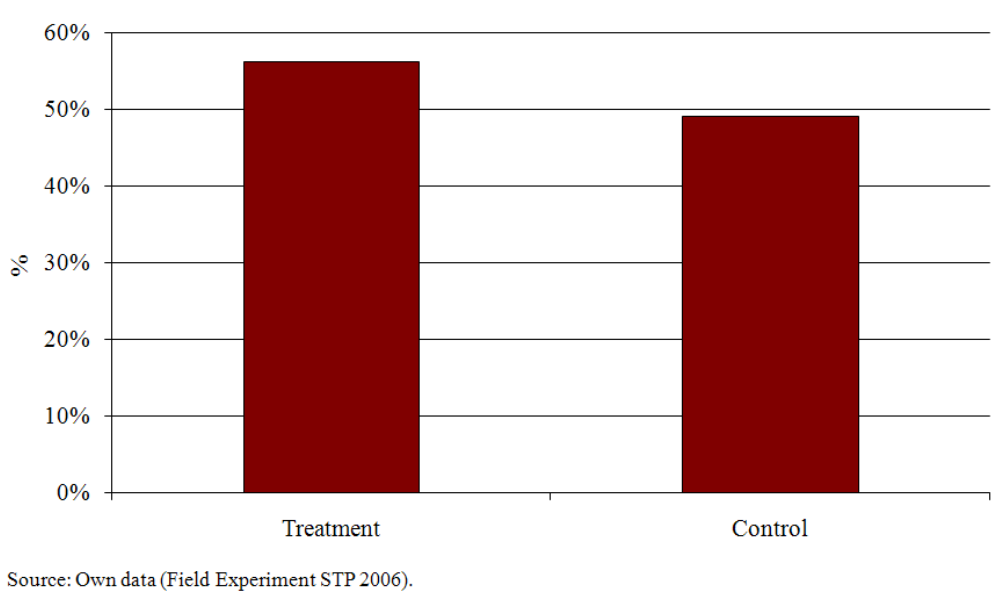

We also conclude from these data that policy platforms are far from stable at the individual level, not only concerning perceptions about the candidates but also regarding own respondents' positions. We display the percentages of respondents that are firm (even if wrongly) regarding priority policies defended by the candidates and by themselves (i.e. report no change in the two policies named across both surveys), and that are flexible (1 or 2 changes across both surveys). We can see in Chart A5 in Appendix that the respondents who do not change their opinion are below $20 \%$ for both the incumbent and themselves, and below $10 \%$ for the challenger. We are 
confident that these data are able to explain some variation in voting behavior (from the intentions of the pre-election survey to the reports of actual conduct in the post-election survey).

\section{Econometric Results}

In a difference-in-differences setting, it is an important standard procedure to verify the exogeneity of the intervention, i.e. to assess the effectiveness of the randomization procedure in setting up similar treatment and control groups. Table A2 in Appendix presents the results of regressions of key demographic variables (for our panel) and of parliamentary election outcomes (actual turnout and voting shares for each location) on the treatment variable. Since these variables are unaffected by the intervention, any differences between treatment and control should be seen as a product of luck. We generally find that differences across both groups are statistically insignificant, which supports a suitable randomization of the anti-vote buying campaign $^{28}$.

We now explore the determinants of vote buying. In Table A3 in Appendix, we analyze the reported prices of votes and the frequency of vote buying on both parliamentary and presidential elections, and vote buying by the incumbent and by the challenger in the respondents' neighborhood or village in the presidential elections only ${ }^{29}$. The first two regression sets are OLS and the last two regression sets are Probits (on the probability of reporting the incumbent/challenger candidacy as undertaking vote buying in the respondent's neighborhood or village; for these regressions, marginal effects are shown in addition to the original regression estimates and statistical significance).

The first specification for each dependent variable includes a dummy variable on urban locations (all areas in the capital district plus Trindade city) and a dummy variable on 'tight competition'/swing zones (where the difference between incumbent and challenger parties, as given in the previous elections is lowest - for simplicity this variable takes value 1 for the 25 out of the 50 surveyed locations where this difference is lowest). In the first two regressions we also

\footnotetext{
${ }^{28}$ Note that we cannot use perceptions of vote buying or voting behavior intentions in the pre-election questionnaire to undertake this exercise provided these are already affected by the treatment (as a way to control for the 'conformity' bias).

${ }^{29}$ The specific questions used were: 'Did you witness any 'banho' in your neighborhood/village in the (March parliamentary or July Presidential) elections? If yes: On average, how much has(have) this(these) party(ies)/candidate(s) spent for a vote in this 'banho'? (Value of VB: local currency) How frequent was this 'banho'? (Frequency of VB: 1-7) Which candidate(s) offered this 'banho'? (VB by Incumbent/Challenger: dummies)'.
} 
include a dummy for parliamentary elections. In the following regressions, we include demographic $^{30}$ and psychological variables ${ }^{31}$, and then add political controls (including our randomized campaign and the observers' presence times) ${ }^{32}$.

Regarding the prices of votes, our basic finding points to these being higher in urban areas. In addition, parliamentary elections appear to yield higher values, as was already clear in the last section. These results are robust across specifications. The coefficient of swing zones is positive though not statistically significant at standard levels.

However, this swing zone effect appears to be an important determinant of the frequency of vote buying and of the vote buying presence of the two candidates. This supports our theory in the sense that all vote buying efforts (included in both candidates' strategies) seem to be directed to swing locations ${ }^{33}$.

The urban area effect, however, changes sign for both the frequency of vote buying and the vote buying presence of the candidates: i.e. rural areas seem to be the focus of vote buying activities. This is consistent with the idea that rural voters may be better targets of 'voting for money' by yielding better enforcement of transactions (lower anonymity in small-scale environments). A comparison with the price evidence seems to indicate that key influential (for the whole country) voters are located in urban areas. Note that consistently with our model, regarding vote buying strategies, both candidates seem to follow a very similar pattern.

\footnotetext{
${ }^{30}$ These variables come from the following rich set of characteristics: Basic Demographics: age, sex (dummy), household size, number of children, nationalities (dummies), ethnic groups (dummies), catholic and non-religious (dummies), marital status (dummies), malaria in the household (dummy); Household Schooling: no schooling (dummy), schooling (1-7), children in primary and secondary school (dummies), fluency of the respondent (1-7); Occupation: sectors (dummies), job insecurity (0-3); Financial Variables: household expenditure (1-7 or in local currency/day), expenditure per capita (1-11 or in local currency/day), loans (0-2), property (dummies). Age and gender are included in all regressions. Individual statistical significance was the criterion pursued for the choice of the remaining variables in specific regressions at the margin.

${ }^{31}$ For each regression we choose psychological proxies from the following list of variables: Conformity variables (agree/disagree 1-7: 'When I am wrong I admit it'; 'I change my mind easily'); degree of comfort/trust concerning the questionnaires (1-7); Pessimism variables (agree/disagree 1-7: 'Good times were those when you were young'; 'The future of STP will be better than the present').

32 The political controls also include variables from the following list: general political indifference (1-5); history of voting for the three main political families (in all elections since 1991) MLSTP/Pinto da Costa, ADI/Trovoada, MDFM/Fradique (dummies); interest in presidential campaign (1-7), participation in presidential campaign (0-28), participation in the ballot process for the presidential election (dummy); knowledge about candidacies (0-2). Individual statistical significance was the criterion for the choice of these variables at the margin.

${ }^{33}$ One can explain that candidates target swing locations instead of swing voters with a lower fixed cost of reaching a more friendly location (where tight competition goes on between the two candidates) - relative to the burden of visiting a less friendly location (dominated by the opponent).
} 
These results on the importance of swing and of rural areas in determining vote buying efforts (in terms of frequency and presence) are generally robust in terms of sign, magnitude and significance to the inclusion of demographic, psychological and political controls.

Table A4 in Appendix displays the regression results for the various vote buying measures we use: witnessed frequency of vote buying, perception of effectiveness of vote buying on voting behavior, perception of 'voting in conscience', and witnessed vote buying values ${ }^{34}$. The OLS specifications used apply first the treatment alone, then add urban, swing, and observers' time variables, then include demographic and psychological controls and finally append political controls (following specification 1 of section 5 above). Note that these political controls use in addition to the bundle described in the last set of regressions (Table A3), measures of changes in knowledge about the existence of the candidacies, changes of policy priorities by the candidates (perceived) and by the respondents, and surprises about the respondents' supporting candidate in the post election survey ${ }^{35}$. In the final specification, we run 2SLS where we instrument the observers' mission time variable with the number of voters registered at each location (consistently with their 'selection rule' as presented in Section 6.3).

We observe treatment effects whose sign is consistent with an effective campaign in decreasing overall frequency and effectiveness (in affecting votes) of vote buying. These effects are clearly significant (at the 1\% level) for both strict effectiveness of vote buying and 'voting in conscience': we detect a $17-21 \%$ impact in decreasing the first and a $22-23 \%$ impact in increasing the second ${ }^{36}$. For witnessed frequency, as expected from last section, we obtain a lower effect (9$11 \%$ effect on decreasing frequency) and significance (at the $10 \%$ level) of the treatment. For witnessed price, we also obtain a negative effect, also at the $10 \%$-level significance. Note that the sign and significance of the estimated effects are generally robust to the inclusion of all controls.

These results are consistent with the idea that campaign effects on vote buying happened primarily through convincing voters not to vote according to money received. However, the reductions in frequency and price are consistent with a small downward shift in the demand for votes (by vote buyers), in a context where actual vote buying transactions (handing/acceptance of

\footnotetext{
${ }^{34}$ The specific questions used for the second and third measures were (1-7): 'How frequent was that 'banho' decided a voter's vote in your village/neighborhood (in the March parliamentary or the July Presidential elections)?' and 'How frequent was that a voter in your village/neighborhood voted following his/her conscience, i.e., voted in the candidate that offered better perspectives of mandate for the country (in the March parliamentary or the July presidential elections)?'.

${ }^{35}$ These variables were always included (all) in these regressions. The ranges of the variables were respectively: 0-2 (number of policy-priority changes), -2 to 4 (difference between knowledge of candidacies in both surveys), and 1-7 (subjective scale).

${ }^{36}$ These values are computed by dividing coefficient estimates by the range of the subjective scale.
} 
gifts, to be precise) seem to be politician-driven. Finally, we also find that the electoral observers do not seem to have clear effects (either on sign or statistical significance) on vote buying.

In the following table in Appendix (Table A5) we show results corresponding to effects of vote buying on voting behavior. These are presented in three sets of regressions. The first takes voter turnout as the dependent variable, since we are mainly interested in testing whether vote buying frequency (witnessed in the respondents' neighborhood or village) works as an energizer of the electorate - according to a STP saying, 'No 'banho', no vote'. This set of regressions includes data on both intended voter turnout (as reported in the pre-election survey) and actual voter turnout (reported in the post-election survey), using all observations stacked (Probit estimations are used). The second set of regressions directly analyzes change in voter turnout for the presidential elections (intended vs. actual reported), where the discrete dependent variable takes value 1 for voters who changed their minds towards voting, value -1 for those who changed towards abstention, and value 0 otherwise (no change). In the final set of regressions, the dependent variable is the change in voting in the presidential elections (intended vs. actual reported). This takes value 1 for changes towards the incumbent, value -1 for changes towards the challenger, and value 0 otherwise. The first specifications in each set of regressions include only the independent variable of interest, then we add basic/structural controls (urban, swing, observers' time), demographic/ psychological controls, and political variables (as in the regressions of Table A4). Note that the second and third sets of regressions follow specification 2 introduced in section 5 above. In those estimations we use Ordered Probit (in face of the discrete nature of the dependent variables ${ }^{37}$ ).

We find that indeed vote buying seems to be inducing more people to vote: this is a clear ( $7 \%$ increase in the probability of voting when considering an increase from lowest to highest vote buying) and highly statistical significant effect (at the $1 \%$ level), which is robust to the various specifications used. Note that endogeneity concerns are diminished by: having individual turnout regressed on location-wide averaged perceptions of vote buying; taking these perceptions in a lagged manner (intentions are contrasted to vote buying data for the parliamentary elections and reports in the post-election survey are compared to vote buying data for the presidential elections).

Concerning the effects of the anti-vote buying campaign on voter turnout change, we do not find a significant effect, although we reach a consistently negative sign. This is unsurprising in face of

\footnotetext{
${ }^{37}$ For robustness, we contrast the Ordered Probit results (implying the estimation of the scale of the dependent variable) with straightforward linear-scale OLS estimates.
} 
the clash between vote buying as an energizer of the electorate and the campaign as actually working against vote buying. Note that even though this campaign had an educational/informative nature, its message was not on increasing turnout but on increasing the quality of voting decisions.

Finally, we find a significant effect of the campaign (which under the results above should be interpreted as exogenous variation on frequency/effectiveness of vote buying) on increasing the likelihood of voting changes (from intentions in the pre-election survey) in the direction of the incumbent. More specifically, we observe a $12 \%$ increase in changes towards the incumbent (when comparing treated with untreated locations, using the -1 to 1 scale referred above). The sign of the coefficient of interest is robust to the various specifications used; statistical significance increases in a stepwise manner with the controls introduced. This result confirms the model prediction that an anti-vote buying intervention just before or contemporaneous to the challenger's vote buying (and after the bulk of the incumbent's move) will be mostly damaging for the challenger's performance. We have, therefore, gathered evidence that vote buying can actually change the voting outcome. This is the main finding of the paper. Our finding is also consistent with the literature on campaign spending effects, which points to the challenger as the main beneficiary of such efforts.

Note that in undertaking this exercise, we are not quantifying the pure effects of vote buying, since these would require measuring, at the individual level, who was exposed to vote buying, by which candidate(s), and different randomized interventions for each candidate. As can be well understood, these are highly demanding conditions to guarantee for any research on vote buying, though we hope can be achieved in future efforts.

Finally, we look at OLS regressions of the difference in the actual official scores of the incumbent vs. the challenger per ballot station, which constitutes the unit of observation (Table A6 in the Appendix; in accordance with specification 3 introduced in section 5 above). We basically want to investigate whether the anti-vote buying campaign had macro-effects (i.e. actually changed the election results). We observe a borderline significant effect (at the $10 \%$ or $15 \%$ level, depending on controls) of the campaign with a consistent (with the panel-based analysis) positive sign (on the range of 6-7 percentage scores in favor of the incumbent). This indicates that the anti-vote buying campaign may have just not been powerful enough to have robust effects at the country level. In addition, interestingly, we find that after accounting for endogeneity of the observers' effort, there is evidence consistent with electoral fraud by the 
incumbent candidacy ${ }^{38}$ : effort by observers diminishes the difference between the scores of the two candidates. We intend to explore this secondary (to what the scope of this paper is concerned) result in future research.

\subsection{Robustness}

We now undertake further specific robustness exercises. We begin by showing evidence of the conformity bias (which led to adjust the design of the measurement technology in our experiment) by running the central regressions in this paper (regarding changes in vote buying outcomes and electoral behavior outcomes on the treatment), but now using the pre-election data only. We display the results in Table A7 in Appendix.

We find effects of the campaign on vote buying perceptions, namely on frequency and voting in conscience. However, whereas the first is a negative coefficient and a positive effect - meaning treated respondents witnessed lower frequency of vote buying in their location in parliamentary elections -, the second is a negative coefficient but a negative effect - in the sense that treated respondents reported less voting in conscience in their location. Our interpretation of this somewhat contradicting finding, is that the first question was taken by respondents as more personal - with respondents protecting themselves against being viewed as vote sellers -, while the second was targeting the euphemism in the slogan of the campaign (voting in conscience), with respondents exaggerating the existence of problems of that type - i.e. stating there was less (relative to control) voting in conscience in the parliamentary elections. We were then able to control for these biases in our design.

We also present some evidence that the same respondents that were influenced by the campaign in terms of reports of vote buying seem to be affected in terms of their voting decisions. This exercise therefore helps on the identification of our main proposed mechanism of action. We repeat the regressions where we found our most important effects (VB impact on voting, toting in conscience, and individual change in voting), but now interacting the treatment with key demographic variables - Chart A8 in Appendix.

This exercise is limited by the fact that questions on vote buying concern 'witnessing in the respondent's neighborhood or village' and not clear individual-level measurement. However, as conveyed above, responses may have (and to a certain extent are expected to have) an individual

\footnotetext{
${ }^{38}$ This result is consistent and comparable with the analysis by Hyde (2006) on the 2003 presidential elections in Armenia. However, in that paper it is argued the deployment of observers 'happened in a manner that approaches randomization'.
} 
component. We indeed find that although statistical significance is not always achieved, patterns of treatment effects are the same for vote buying (first two regressions in each set) and voting behavior (third regression) for age, schooling, main occupation, and household expenditure. More specifically, older, less educated, traders, and (clearly) lower-income respondents seem to be more responsive to the campaign.

Finally we provide a standard test, generally useful in the analysis of location-wide treatments in experiments. We test whether there was contamination of the randomized intervention from treatment to control locations. In the affirmative case, this would represent an underestimation of our effects of interest. To address this problem, we run the same key regressions we have analyzed above, but focusing on the control group and using as treatment the distance to the closest location where the randomized campaign was undertaken.

We show these results in Table A9 in the Appendix. We find no significant effects of distance except for VB Frequency, for which an opposite sign to the one expected as impact of the campaign (shown above) is observed. Namely, we find a negative effect (distance to treatment diminishing vote buying). This enables us to conclude for no clear effects of the campaign in control locations (no clear contamination), which ensures us of the precision of the estimates presented for our main experimental research questions.

\section{Concluding Remarks}

This paper makes a methodological contribution to the literature by proposing a difference-indifferences randomized design to target concealed determinants of electoral behavior, as means to deepening our understanding of the creation of political institutions. The proposed technique may be applied to the study of many prominent phenomena in emerging democracies like vote buying, electoral fraud, or violence/intimidation. It addresses the well-known difficulty in having the crucial exogenous empirical variation in political variables that enables a reliable understanding of causality.

Our main findings provide evidence that vote buying is effective in changing voting preferences/behavior. In particular, when compared with the incumbent, the challenger seems to benefit more from vote buying (consistently with much of the empirical literature on campaign spending effectiveness). In addition, we show that vote buying seems to energize the electorate.

In terms of real-world implications, this paper underlines that vote buying in democratic countries similar to STP may be biasing the balance of power towards a rich elite. Generally, vote buying constitutes a form of appeasement of the population that is not conditional on policy. If vote 
buying is the main source of 'politicians' accountability', and if it is effective in driving the electorate (as specifically concluded in this paper), policies will necessarily favor the rich elite. This implication may be especially problematic in countries like STP where rent-seeking policies are pervasive, and significant oil revenues are expected in the future. It is well known that the natural resource curse feeds itself on poor political institutions.

Our results also provide some good news for policy-making, by showing that an informational/sensitization campaign (sponsored by an electoral commission) targeting vote buying may be effective in diminishing its impact, therefore contributing to the undermining of this phenomenon, and potentially to the increasing of policy accountability.

A further note goes to the need to shed more light into the mechanisms of enforcement of vote buying transactions. Although we carried out some descriptive work on this issue, we are convinced specific causal work can be applied.

We hope this paper may contribute (with its microeconomic method and results) to convince researchers and policy makers of the importance of deepening the empirical study of election malfeasance in the developing world. Our knowledge of 'institutional quality' in economic development may benefit from such efforts. 


\section{References}

Abramowitz, Alan I. (1988), Explaining Senate Election Outcomes, American Political Science Review, 82(2), pp. 385-403;

Ansolabehere, Stephen, John de Figueiredo, and James M. Snyder, Jr. (2003), Why Is There So Little Money in U.S. Politics?, Journal of Economic Perspectives, 17(1), pp. 105-130;

Becker, Gary S. (1983), A Theory of Competition among Pressure Groups for Political Influence, Quarterly Journal of Economics, 98(3), pp. 371-400;

Brusco, Valeria, Marcelo Nazareno, and Susan C. Stokes (2004), Vote Buying in Argentina, Latin American Research Review, 39(2), pp. 66-88;

Cox, Gary W. (1987), The Efficient Secret: The Cabinet and the Development of Political Parties in Victorian England, Cambridge University Press;

Cox, Gary W. and J. Morgan Kousser (1981), Turnout and Rural Corruption: New York as a Test Case, American Journal of Political Science, 25(4), pp. 646-663;

Dekel, Eddie, Matthew O. Jackson, and Asher Wolinsky (2006), Vote Buying I: General Elections, Stanford University, Working Paper;

Dixit, Avinash, and John Londregan (1996), The Determinants of Special Interests in Redistributive Politics, Journal of Politics, 58(4), pp. 1132-1155;

Erikson, Robert S. and Thomas R. Palfrey (2000), Equilibria in Campaign Spending Games: Theory and Data, American Political Science Review, 94(3), pp. 595-609;

Frynas, Jedrzej G., Geoffrey Wood, and Ricardo S. Oliveira (2003), Business and Politics in São Tomé and Príncipe: From Cocoa Monoculture to Petro-State, African Affairs, 102(1), pp. 51-80;

Gerber, Alan S. (1998), Estimating the Effect of Campaign Spending on Senate Election Outcomes Using Instrumental Variables, American Political Science Review, 92(2), pp. 401411

Gerber, Alan S. (2004), Does Campaign Spending Work? Field Experiments Provide Evidence and Suggest New Theory, American Behavioral Scientist, 47(5), pp. 541-574;

Gerber, Alan S. and Donald P. Green (2000), The Effects of Canvassing, Telephone Calls, and Direct Mail on Voter Turnout: A Field Experiment, American Political Science Review, 94(3), pp. 653-663.

Green, Donald P. and Jonathan S. Krasno (1988), Salvation for the Spendthrift Incumbent: Reestimating the Effects of Campaign Spending in House Elections, American Journal of Political Science, 32(4), pp. 884-907;

Grossman, Gene M., and Elhanan Helpman (1996), Electoral Competition and Special Interest Politics, Review of Economic Studies, 63(2), pp. 265-286;

Hyde, Susan (2006), Can International Election Observers Deter Election Day Fraud? Evidence from a Natural Experiment, Yale University, mimeograph;

Jacobson, Gary C. (1978), The Effects of Campaign Spending in Congressional Elections, American Political Science Review, 72(2), pp. 469-491;

Jacobson, Gary C. (1985), Money and Votes Reconsidered: Congressional Elections, 1972-1982, Public Choice, 47, pp. 7-62; 
Jacobson, Gary C. (1990), The Effects of Campaign Spending in House Elections: New Evidence for Old Arguments, American Journal of Political Science, 34(2), pp. 334-362;

Levitt, Steven D. (1994), Using Repeat Challengers to Estimate the Effect of Campaign Spending on Election Outcomes in U.S. House, Journal of Political Economy, 102(4), pp. 777-798;

Mehlum, Halvor, Karl Moene and Ragnar Torvik (2006), Institutions and the Resource Curse, The Economic Journal, 116(508), pp. 1-20;

Philipson, Thomas J., and James M. Snyder (1996), Equilibrium and Efficiency in an Organized Voting Market, Public Choice, 89, pp. 245-265;

Prat, Andrea, Riccardo Puglisi, and James M. Snyder, Jr. (2006), Is Private Campaign Finance a Good Thing? Estimates of the Potential Informational Benefits, LSE and MIT, Working Paper;

Roberson, Brian (2006), The Colonel Blotto Game, Economic Theory, 29(1), pp. 1-24;

Sachs, Jeffrey D. and Andrew M. Warner (1995), Natural Resource Abundance and Economic Growth, NBER, Working Paper 5398;

Seibert, Gerhard (2006), Comrades, Clients and Cousins: Colonialism, Socialism and Democratization in São Tomé and Príncipe, $2^{\text {nd }}$ Edition, Brill Academic Publishers;

Vicente, Pedro C. (2006), Does Oil Corrupt? Evidence from a Natural Experiment in West Africa, Oxford University, mimeograph;

Vicente, Pedro C. (2007), Corrupted Scholarships, Oxford University, mimeograph;

Wantchekon, Leonard (2003), Clientelism and Voting Behavior: Evidence from a Field Experiment in Benin, World Politics, 55, pp. 399-422;

Weiss, Jeffrey H. (1988), Is Vote-selling Desirable?, Public Choice, 59, pp. 159-194. 


\section{Appendix}

\section{A.1 Sample and Campaign}

\section{Sao Tome Island Map - Treatment and Control Areas}

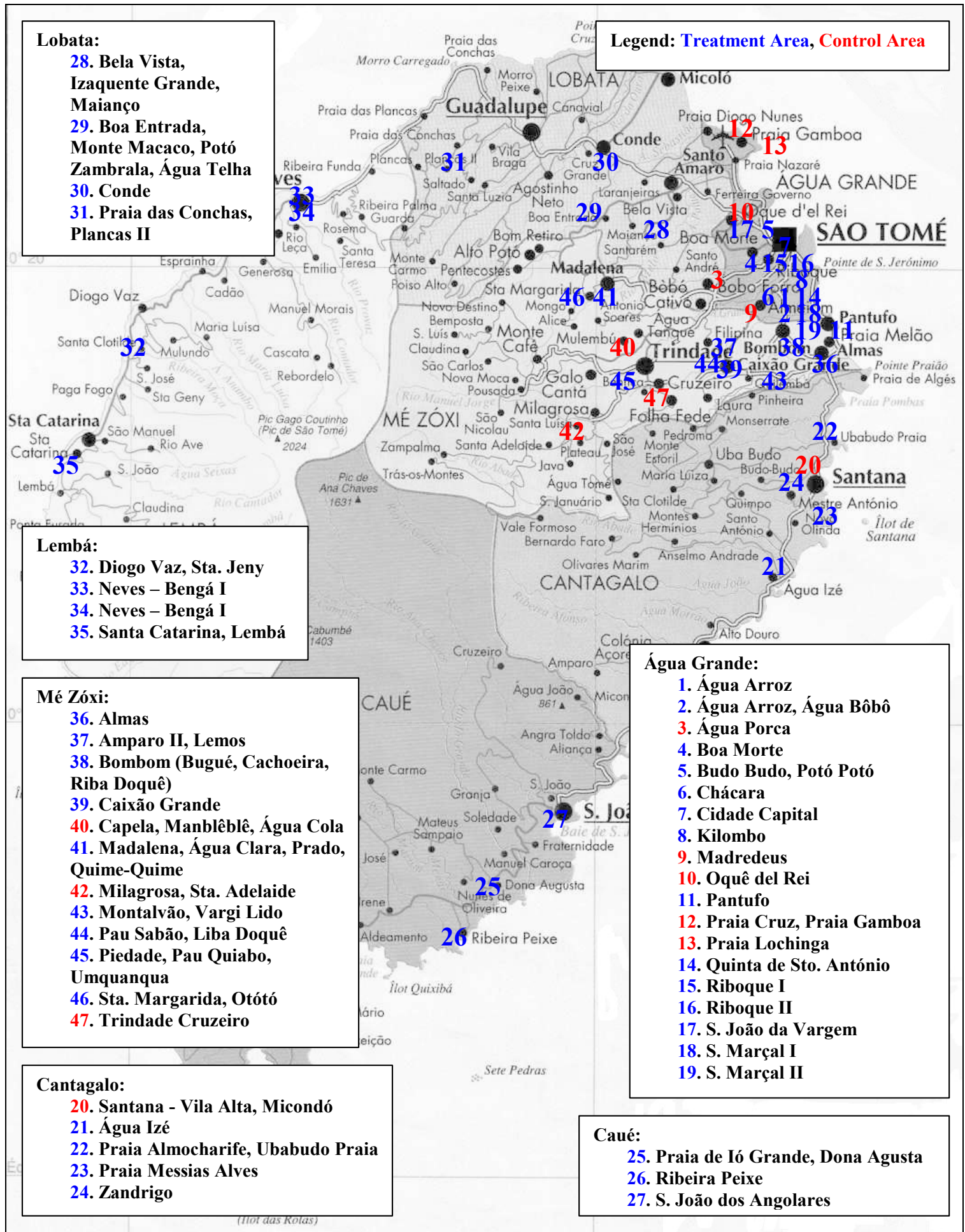




\section{Principe Island Map - Treatment and Control Areas}

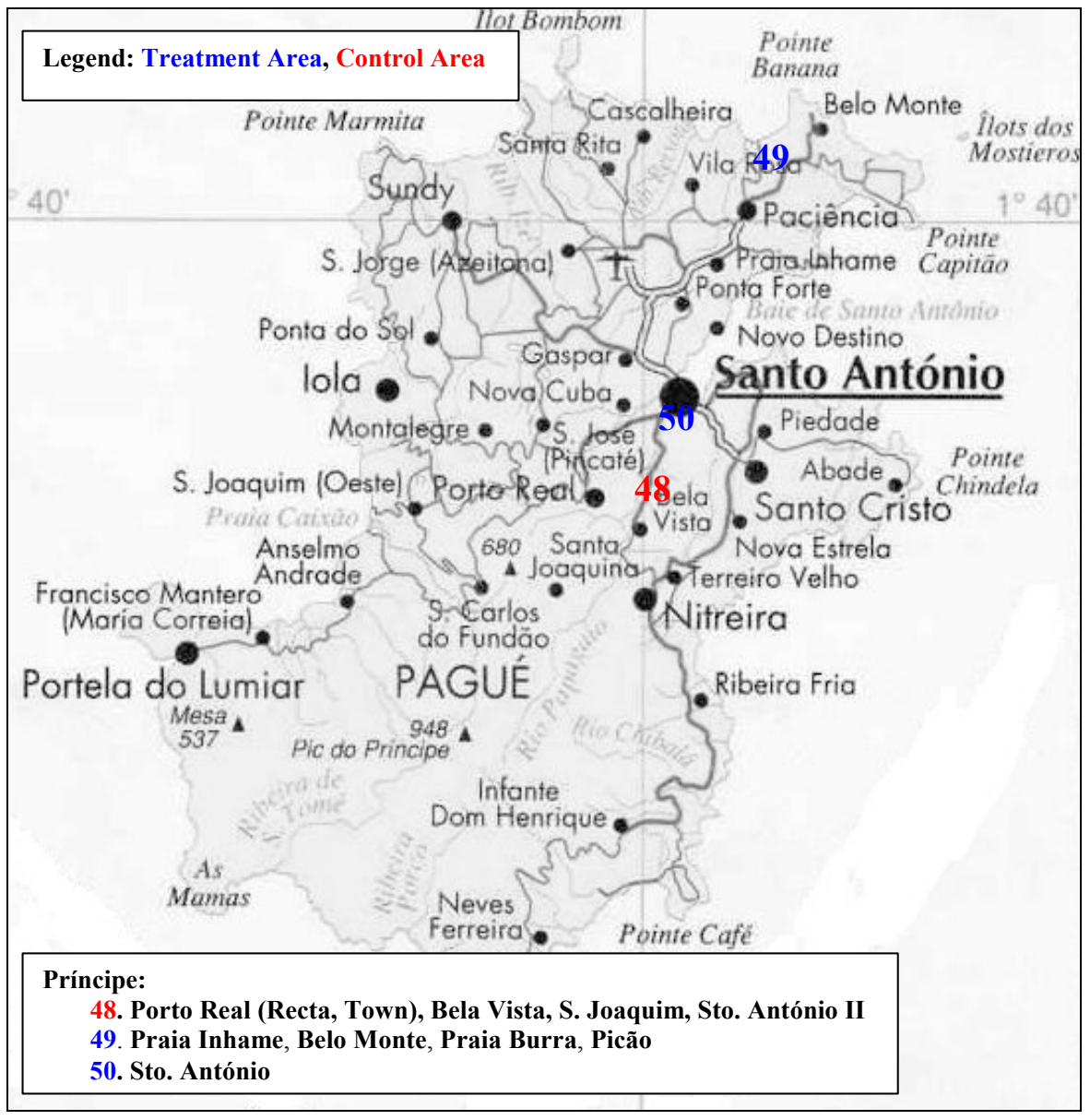


Table A1: Survey Sample

\begin{tabular}{|c|c|c|c|c|c|c|c|}
\hline & \multicolumn{3}{|c|}{ Pre-Election Survey } & \multicolumn{3}{|c|}{ Post-Election Survey } & \multirow[b]{2}{*}{$\begin{array}{c}\% \text { Re- } \\
\text { Surveyed }\end{array}$} \\
\hline & \# Interviews & \begin{tabular}{|c|} 
Non- \\
respondents
\end{tabular} & $\begin{array}{c}\text { Total } \\
\text { Attempted }\end{array}$ & \# Interviews & \begin{tabular}{c|} 
Non- \\
respondents
\end{tabular} & $\begin{array}{c}\text { Total } \\
\text { Attempted }\end{array}$ & \\
\hline (AG) Água Arroz & 23 & 4 & 27 & 18 & 5 & 23 & $\overline{78 \% \%}$ \\
\hline (AG) Água Arroz e Água Bôbô & 19 & 0 & 19 & 13 & 6 & 19 & $68 \%$ \\
\hline (AG) Água Porca & 25 & 4 & 29 & 18 & 7 & 25 & $72 \%$ \\
\hline (AG) Boa Morte & 29 & 5 & 34 & 21 & 8 & 29 & $72 \%$ \\
\hline (AG) Budo Budo, Potó Potó & 21 & 8 & 29 & 18 & 3 & 21 & $86 \%$ \\
\hline (AG) Chacara & 22 & 1 & 23 & 15 & 7 & 22 & $68 \%$ \\
\hline (AG) Cidade Capital & 4 & 0 & 4 & 4 & 0 & 4 & $100 \%$ \\
\hline (AG) Kilombo & 20 & 4 & 24 & 14 & 6 & 20 & $70 \%$ \\
\hline (AG) Madredeus & 28 & 6 & 34 & 22 & 6 & 28 & $79 \%$ \\
\hline (AG) Oquê del Rei & 24 & 4 & 28 & 20 & 4 & 24 & $83 \%$ \\
\hline (AG) Pantufo & 33 & 8 & 41 & 21 & 12 & 33 & $64 \%$ \\
\hline (AG) Praia Cruz, Praia Gamboa & 34 & 9 & 43 & 31 & 3 & 34 & $91 \%$ \\
\hline (AG) Praia Lochinga & 28 & 2 & 30 & 26 & 2 & 28 & $93 \%$ \\
\hline (AG) Riboque I & 46 & 7 & 53 & 37 & 9 & 46 & $80 \%$ \\
\hline (AG) Riboque II & 26 & 7 & 33 & 16 & 10 & 26 & $62 \%$ \\
\hline (AG) S. João Vargem & 30 & 8 & 38 & 22 & 8 & 30 & $73 \%$ \\
\hline (AG) S. Marçal I & 31 & 8 & 39 & 23 & 8 & 31 & $74 \%$ \\
\hline (AG) S. Marçal II & 21 & 1 & 22 & 18 & 3 & 21 & $86 \%$ \\
\hline (AG) Sto. António & 23 & 3 & 26 & 18 & 5 & 23 & $78 \%$ \\
\hline (C) Praia de Ió Grande, Dona Agusta & 30 & 0 & 30 & 25 & 5 & 30 & $83 \%$ \\
\hline (C) Ribeira Peixe & 27 & 1 & 28 & 23 & 4 & 27 & $85 \%$ \\
\hline (C) S. João dos Angolares & 29 & 0 & 29 & 25 & 4 & 29 & $86 \%$ \\
\hline (Ca) Água Izé & 23 & 0 & 23 & 21 & 2 & 23 & $91 \%$ \\
\hline (Ca) Praia Almocharife, Ubabudo Praia & 21 & 2 & 23 & 17 & 4 & 21 & $81 \%$ \\
\hline (Ca) Praia Messias Alves & 28 & 6 & 34 & 24 & 4 & 28 & $86 \%$ \\
\hline (Ca) Santana - Vila Alta, Micondó & 26 & 1 & 27 & 18 & 8 & 26 & $69 \%$ \\
\hline (Ca) Zamdrigo & 26 & 0 & 26 & 20 & 6 & 26 & $77 \%$ \\
\hline (Le) Diogo Vaz, Sta. Jeny & 24 & 0 & 24 & 21 & 3 & 24 & $88 \%$ \\
\hline (Le) Neves - Benga I & 30 & 1 & 31 & 24 & 6 & 30 & $80 \%$ \\
\hline (Le) Neves - Benga II & 18 & 1 & 19 & 17 & 1 & 18 & $94 \%$ \\
\hline (Le) Santa Catarina, Lembá & 26 & 3 & 29 & 21 & 5 & 26 & $81 \%$ \\
\hline (Lo) Bela Vista, Izaquente Grande, Maianço & 23 & 0 & 23 & 21 & 2 & 23 & $91 \%$ \\
\hline (Lo) Boa Entrada, Monte Macaco, Potó Zambrala, Água Telha & 23 & 0 & 23 & 20 & 3 & 23 & $87 \%$ \\
\hline (Lo) Conde & 21 & 2 & 23 & 21 & 0 & 21 & $100 \%$ \\
\hline (Lo) Praia das Conchas, Plancas II & 26 & 1 & 27 & 23 & 3 & 26 & $88 \%$ \\
\hline (MZ) Almas & 25 & 3 & 28 & 17 & 8 & 25 & $68 \%$ \\
\hline (MZ) Amparo II, Lemos & 26 & 6 & 32 & 20 & 6 & 26 & $77 \%$ \\
\hline (MZ) Bombom (Bugué, Cachoeira, Riba Doquê) & 25 & 1 & 26 & 22 & 3 & 25 & $88 \%$ \\
\hline (MZ) Caixão Grande & 22 & 2 & 24 & 15 & 7 & 22 & $68 \%$ \\
\hline (MZ) Capela, Manblêblê, Água Cola & 28 & 8 & 36 & 21 & 7 & 28 & $75 \%$ \\
\hline (MZ) Madalena, Água Clara, Prado, Quime-Quime & 22 & 1 & 23 & 17 & 5 & 22 & $77 \%$ \\
\hline (MZ) Milagrosa, Sta. Adelaide & 30 & 0 & 30 & 29 & 1 & 30 & $97 \%$ \\
\hline (MZ) Montalvão, Vargi Lido & 28 & 3 & 31 & 23 & 5 & 28 & $82 \%$ \\
\hline (MZ) Pau Sabão, Liba Doquê & 23 & 2 & 25 & 21 & 2 & 23 & $91 \%$ \\
\hline (MZ) Piedade, Pau Quiabo, Umquanqua & 27 & 1 & 28 & 22 & 5 & 27 & $81 \%$ \\
\hline (MZ) Sta. Margarida, Otótó & 25 & 2 & 27 & 21 & 4 & 25 & $84 \%$ \\
\hline (MZ) Trindade - Cruzeiro & 27 & 6 & 33 & 24 & 3 & 27 & $89 \%$ \\
\hline 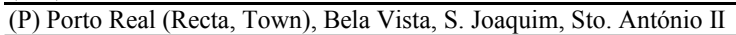 & 20 & 0 & 20 & 17 & 3 & 20 & $85 \%$ \\
\hline (P) Praia Inhame, Belo Monte, Praia Burra, Picão & 23 & 0 & 23 & 20 & 3 & 23 & $87 \%$ \\
\hline (P) Sto. António & 36 & 0 & 36 & 29 & 7 & 36 & $81 \%$ \\
\hline Total & 1275 & |141| & 1416 & 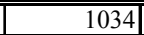 & 241 & 1275 & $81 \%$ \\
\hline
\end{tabular}




\section{The Anti-Vote Buying Campaign - Leaflet Used (front and back)}

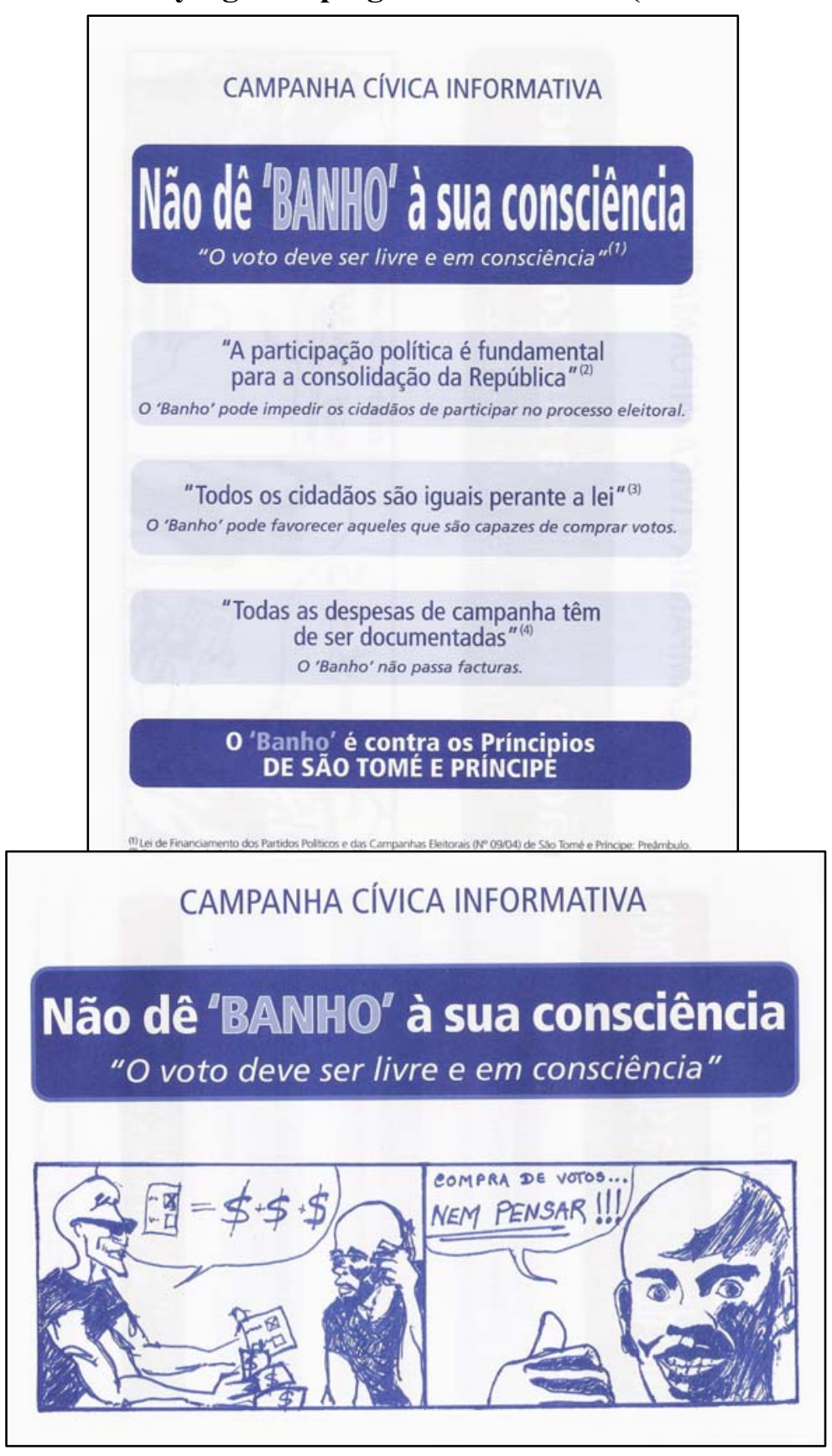

The main slogan is 'Do not let your conscience have a 'banho' - Your vote should be free and in good conscience'. The front page features three passages of the STP law (Constitution and Campaign Financing Law). The figure below presents a voter saying: 'Vote Buying... No way!!!’. 


\section{A.2 Charts}

Chart A1: How Was Vote Buying Seen by the Population before the Campaign?

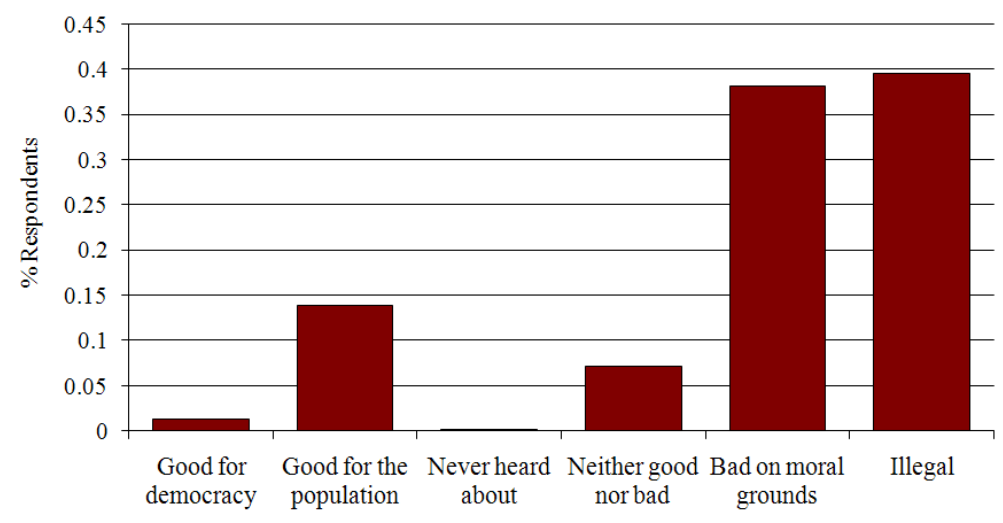

Source: Own data (Field Experiment STP 2006). 
Chart A2: Vote Buying Presence by Candidates $\%$ Reporting

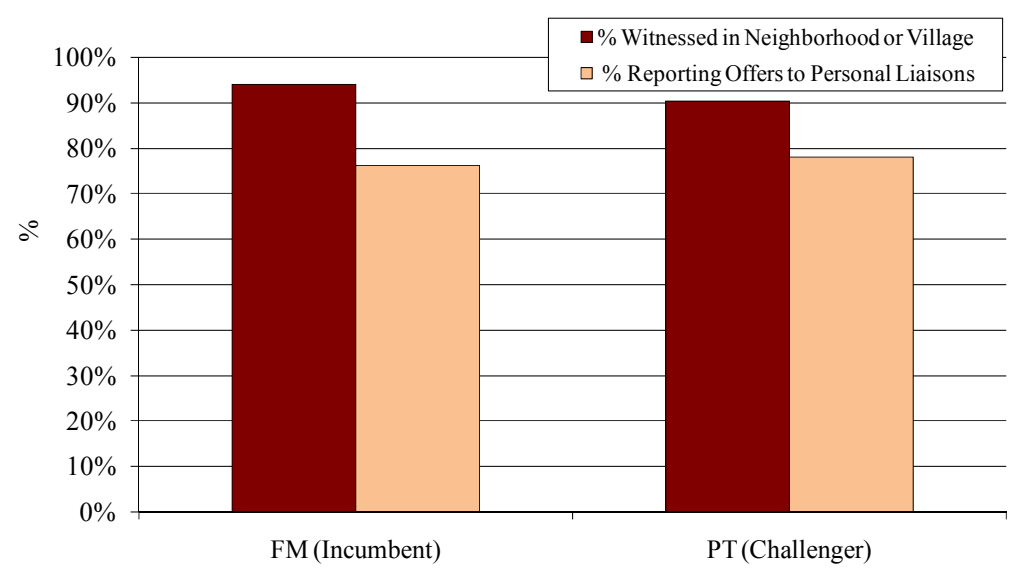

Source: Own data (Field Experiment STP 2006). 
Chart A3: Information about Presidential Candidacies

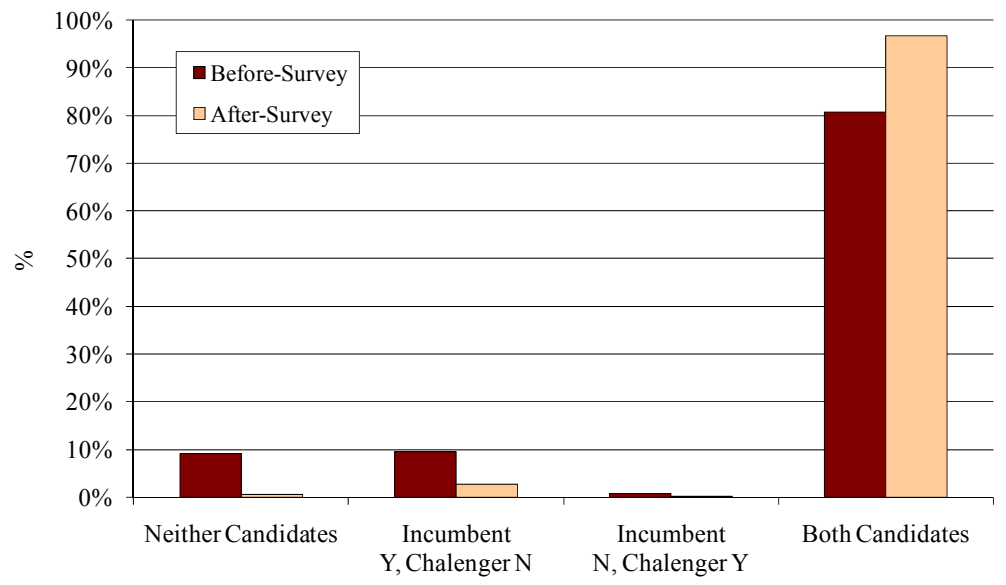

Source: Own data (Field Experiment STP 2006).

Chart A4: Most Important Policy Issues for Candidates and Respondents

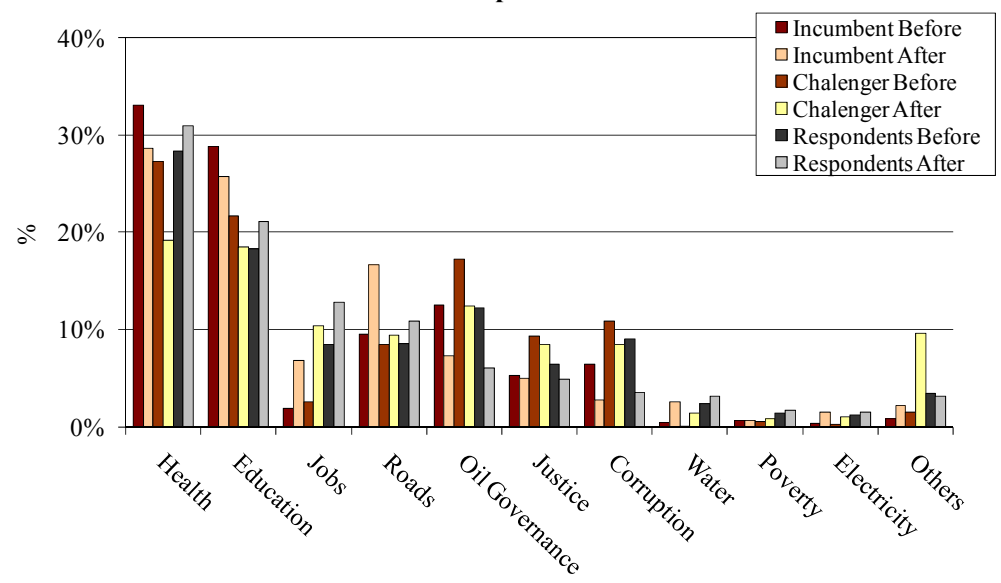

Source: Own data (Field Experiment STP 2006).

Chart A5: Average Number of Changes in Most Important Issues for Candidates and Respondents

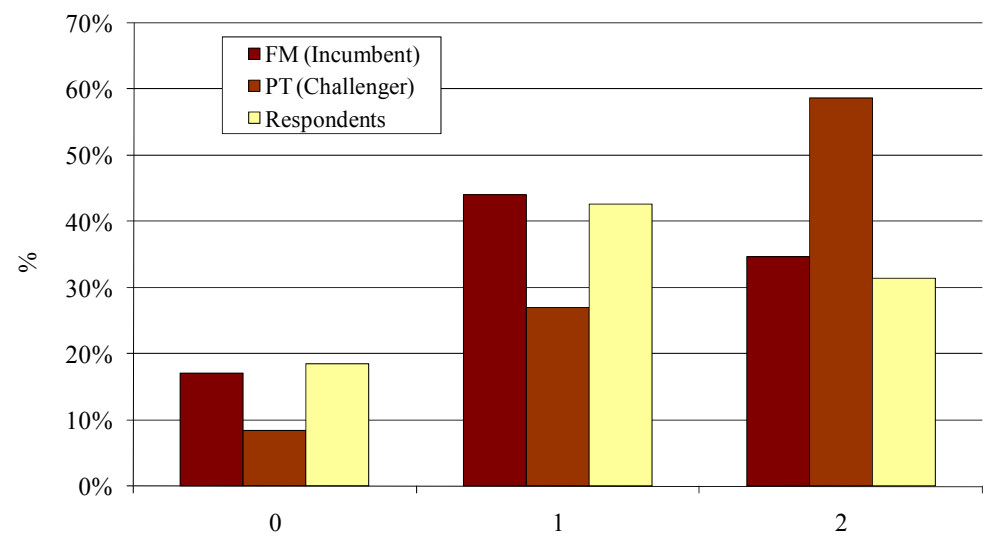

Source: Own data (Field Experiment STP 2006). 


\section{A.3 Regression Tables}

Table A2: Are Treated Respondents/Locations Different from their Control Counterparts?

\begin{tabular}{|c|c|c|c|c|c|}
\hline & & Control & Treatment & Difference & $\begin{array}{c}\text { Number of } \\
\text { Observations }\end{array}$ \\
\hline \multirow{18}{*}{$\begin{array}{c}\text { Demographics } \\
\text { (Individual Level) }\end{array}$} & \multirow{2}{*}{ age (years) } & \multirow{2}{*}{37.75} & \multirow{2}{*}{37.45} & -0.3 & \multirow{2}{*}{1273} \\
\hline & & & & 1.63 & \\
\hline & \multirow{2}{*}{ catholic (\%) } & \multirow{2}{*}{0.68} & \multirow{2}{*}{0.73} & 0.05 & \multirow{2}{*}{1262} \\
\hline & & & & 0.05 & \\
\hline & \multirow{2}{*}{ household size } & \multirow{2}{*}{5.19} & \multirow{2}{*}{5.27} & 0.08 & \multirow{2}{*}{1274} \\
\hline & & & & 0.22 & \\
\hline & \multirow{2}{*}{ married (\%) } & \multirow{2}{*}{0.04} & \multirow{2}{*}{$\mathbf{0 . 0 3}$} & -0.01 & \multirow{2}{*}{1274} \\
\hline & & & & 0.01 & \\
\hline & \multirow{2}{*}{ education (1-7) } & \multirow{2}{*}{3.35} & \multirow{2}{*}{3.3} & -0.05 & \multirow{2}{*}{1274} \\
\hline & & & & 0.12 & \\
\hline & \multirow{2}{*}{ occupation - agriculture (\%) } & \multirow{2}{*}{0.09} & \multirow{2}{*}{0.1} & 0.01 & \multirow{2}{*}{1266} \\
\hline & & & & 0.05 & \\
\hline & \multirow{2}{*}{ occupation - public administration (\%) } & \multirow{2}{*}{0.03} & \multirow{2}{*}{$\mathbf{0 . 0 3}$} & $\mathbf{0}$ & \multirow{2}{*}{1266} \\
\hline & & & & 0.01 & \\
\hline & \multirow{2}{*}{ household expenditure (USD/day) } & \multirow{2}{*}{64.92} & \multirow{2}{*}{64.64} & -0.28 & \multirow{2}{*}{1260} \\
\hline & & & & 5.69 & \\
\hline & \multirow{2}{*}{ land (\% owning) } & 0.51 & 0.46 & -0.05 & 1244 \\
\hline & & 0.01 & 0.40 & 0.09 & \\
\hline & turnout (narliamentary elections) (\%) & 0.62 & 0.65 & 0.03 & 50 \\
\hline & & & & 0.04 & \\
\hline Electoral Behavior & incumbent party (parliamentary elections) & 041 & 0.38 & -0.03 & 50 \\
\hline (Location-Level) & $(\%)$ & & & 0.04 & 30 \\
\hline & difference incumbent-challenger parties & 023 & 018 & -0.05 & 50 \\
\hline & (parliamentary elections) $(\%)$ & 0.25 & 0.18 & 0.06 & \\
\hline
\end{tabular}

Note: Standard errors reported; these are corrected by clustering at the location (census area) level (for individual-level regressions).

* significant at $10 \%$;* significant at $5 \%$; ** significant at $1 \%$.

These results come from OLS regressions. 
Table A3: Regressions of Determinants of Vote Buying

\begin{tabular}{|c|c|c|c|c|c|c|c|c|c|c|c|c|c|c|c|c|c|c|c|c|}
\hline & \multicolumn{2}{|c|}{ Dependent Variable ----->> } & \multirow{3}{*}{\multicolumn{3}{|c|}{$\begin{array}{c}\text { Value }(\mathrm{t}=\mathbf{0 , 1}) \\
\text { OLS } \\
\end{array}$}} & \multirow{3}{*}{\multicolumn{3}{|c|}{$\begin{array}{c}\text { VB Frequency }(t=1) \\
\text { OLS }\end{array}$}} & \multirow{2}{*}{\multicolumn{6}{|c|}{$\begin{array}{c}\text { Incumbent VB }(t=1) \\
\text { Probit }\end{array}$}} & \multirow{2}{*}{\multicolumn{6}{|c|}{$\begin{array}{c}\text { Challenger VB }(t=1) \\
\text { Probit }\end{array}$}} \\
\hline & & & & & & & & & & & & & & & & & & & & \\
\hline & & & & & & & & & & ME & & ME & & ME & & ME & & ME & & ME \\
\hline \multirow{7}{*}{$\begin{array}{c}\text { Main Explanatory } \\
\text { Variables }\end{array}$} & \multirow{2}{*}{ parl } & coef & 186.1 & 160.27 & 190.91 & 2.01 & 2.01 & 1.75 & & & & & & & & & & & & \\
\hline & & std err & $55.29 * * * 1$ & 46.60 **: & $76.62 * *$ & $0.14^{* * * *}$ & $0.14^{* * * *}$ & $0.32 * * *$ & & & & & & & & & & & & \\
\hline & \multirow{2}{*}{ urban } & coef & 215.48 & 162.72 & 139.99 & -0.33 & -0.47 & -0.49 & -0.25 & \multirow{2}{*}{-0.1} & -0.27 & \multirow{2}{*}{-0.1} & -0.24 & \multirow{2}{*}{-0.09} & -0.2 & \multirow{2}{*}{-0.08} & -0.26 & \multirow{2}{*}{-0.1} & -0.26 & \multirow{2}{*}{-0.1} \\
\hline & & std err & $94.51 * *$ & $76.84 * *$ & $68.57 * *$ & $0.17^{*}$ & $0.18^{* *}$ & $0.18^{* * *}$ & $0.12 * *$ & & $0.13^{* *}$ & & $0.13^{*}$ & & $0.11 *$ & & $0.11 * *$ & & $0.11^{* *}$ & \\
\hline & swing & coef & 63.85 & 59.56 & 78.49 & 0.31 & 0.41 & 0.47 & 0.2 & \multirow{2}{*}{0.08} & 0.3 & \multirow{2}{*}{0.12} & 0.33 & \multirow{2}{*}{0.12} & 0.13 & \multirow{2}{*}{0.05} & 0.22 & \multirow{2}{*}{0.09} & 0.19 & \multirow{2}{*}{0.08} \\
\hline & \multirow{3}{*}{ Constant } & Jsta err & $6 \% .15$ & 69.66 & 11.81 & $0.18^{\circ}$ & $0.18^{n+4}$ & $0.19^{* *}$ & 0.13 & & $0.13^{* \pi}$ & & $0.14^{* *}$ & & 0.11 & & $0.11 \times+4$ & & $0.12^{*}$ & \\
\hline & & foer & -32.54 & 71.14 & 102.32 & 2.62 & 0.72 & 0.91 & 0.27 & & 0.68 & & 0.5 & & 0.22 & & 0.07 & & -0.39 & \\
\hline \multirow{2}{*}{\multicolumn{3}{|c|}{ Demographic \& Psychological Controls }} & & & & & & & \multirow{2}{*}{\multicolumn{2}{|c|}{ No }} & \multirow{2}{*}{\multicolumn{2}{|c|}{$\overline{\text { Yes }}$}} & \multirow{2}{*}{\multicolumn{2}{|c|}{$\overline{\text { Yes }}$}} & \multirow{2}{*}{\multicolumn{2}{|c|}{ No }} & \multirow{2}{*}{\multicolumn{2}{|c|}{ Yes }} & $0.1 \mathrm{~J}$ & \\
\hline \multirow{2}{*}{\multicolumn{3}{|c|}{ Political Controls (inc. Interventions) }} & & & & & & & & & & & & & & & & & \multicolumn{2}{|c|}{$\overline{\text { Yes }}$} \\
\hline & & & 100 & 100 & Yes & $\mathrm{No}$ & $\mathrm{No}$ & Yes & \multicolumn{2}{|c|}{ No } & \multicolumn{2}{|c|}{ No } & $\underline{Y}$ & & & & & & & \\
\hline$\frac{\mathrm{Nu}}{\text { Adjusted R-so }}$ & d(OLS) Lik Ra & (P) & 0.03 & 0.02 & $\frac{1105}{0.02}$ & 0.17 & $\frac{1741}{0.21}$ & $\frac{1075}{0.24}$ & $\frac{10}{5}$ & & 445 & & $\frac{01}{65}$ & & $\frac{10}{4}$ & & & & & \\
\hline
\end{tabular}

Note: Standard errors reported; these are corrected by clustering at the location (census area) level. * significant at $10 \%$; ** significant at $5 \%$; *** significant at $1 \%$.

The value regressions correspond to stacked regressions for pre and post-election data (on both Parliamentary and Presidential Elections).

All other regressions concern post-election data (on the Presidential elections). ME stands for Marginal Effects. 
Table A4: Regressions of Change in Vote Buying

\begin{tabular}{|c|c|c|c|c|c|c|c|c|c|c|c|c|}
\hline & \multicolumn{2}{|c|}{ Dependent Variable ------> } & \multicolumn{5}{|c|}{ Change in VB Frequency } & \multicolumn{5}{|c|}{ Change in VB Impact } \\
\hline & & & \multicolumn{4}{|c|}{ OLS } & IV & \multicolumn{4}{|c|}{ OLS } & IV \\
\hline \multirow{10}{*}{$\begin{array}{l}\text { Main Explanatory } \\
\text { Variables }\end{array}$} & \multirow{2}{*}{ treatment } & coef & -0.29 & 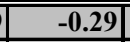 & -0.21 & -0.66 & -0.52 & -0.94 & -0.96 & -0.92 & -1.28 & -1.03 \\
\hline & & std err & 0.37 & 0.34 & 0.35 & $0.35^{*}$ & 0.45 & $0.27 * * *$ & $0.26^{* * *}$ & $0.25^{* * *}$ & $0.32 * * *$ & $0.53^{*}$ \\
\hline & \multirow{2}{*}{ urban } & coef & & 0.15 & 0 & -0.1 & -0.15 & & 0.07 & 0.03 & -0.27 & -0.37 \\
\hline & & std err & & 0.3 & 0.32 & 0.35 & 0.39 & & 0.27 & 0.26 & 0.29 & 0.37 \\
\hline & \multirow{2}{*}{ swing } & coef & & 0.45 & 0.38 & 0.4 & 0.19 & & 0.18 & 0.12 & -0.21 & -0.56 \\
\hline & & std err & & 0.34 & 0.35 & 0.41 & 0.57 & & 0.3 & 0.29 & 0.31 & 0.41 \\
\hline & \multirow{2}{*}{ observer (inst by pop) } & coef & & -0.17 & -0.11 & -0.13 & 0.05 & & -0.1 & -0.08 & -0.06 & 0.27 \\
\hline & & std err & & $0.06 * * *$ & $0.06^{*}$ & $0.06^{* *}$ & 0.26 & & 0.07 & 0.06 & 0.08 & 0.22 \\
\hline & \multirow{2}{*}{ Constant } & coef & -1.91 & -1.86 & -0.61 & 4.15 & 3.92 & -0.99 & -0.89 & -0.82 & 0.23 & -0.26 \\
\hline & & std err & $0.33^{* * *}$ & $0.40 * * *$ & 1.33 & $1.07 * * *$ & $1.07 * * *$ & $0.23 * * *$ & $0.30^{* * *}$ & 0.74 & 1.1 & 1.2 \\
\hline \multicolumn{3}{|c|}{ Demographic \& Psychological Controls } & No & No & Yes & Yes & Yes & No & No & Yes & Yes & Yes \\
\hline \multicolumn{3}{|c|}{$\begin{array}{l}\text { Political Controls } \\
\end{array}$} & No & No & No & Yes & Yes & No & No & No & Yes & Yes \\
\hline \multirow{2}{*}{\multicolumn{3}{|c|}{$\begin{array}{c}\text { Number of Observations } \\
\text { Adjusted R-squared (OLS) F-stat (IV) } \\
\end{array}$}} & 988 & 988 & 883 & 387 & 387 & 1005 & 1005 & 987 & 427 & 427 \\
\hline & & & 0 & 0.01 & 0.04 & 0.17 & 24.3 & 0.03 & 0.03 & 0.05 & 0.09 & 6.06 \\
\hline & \multicolumn{2}{|c|}{ Dependent Variable --.---> } & \multicolumn{5}{|c|}{ 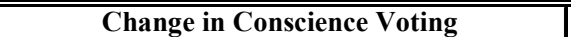 } & \multicolumn{5}{|c|}{ Change in VB Value } \\
\hline & & & \multicolumn{4}{|c|}{ OLS } & IV & \multicolumn{4}{|c|}{ OLS } & IV \\
\hline \multirow{10}{*}{$\begin{array}{c}\text { Main Explanatory } \\
\text { Variables }\end{array}$} & \multirow{2}{*}{ treatment } & coef & 0.85 & 0.91 & 1.03 & 1.4 & 1.32 & -38.2 & \begin{tabular}{l|l|}
-52.67 \\
\end{tabular} & -45.02 & -203.21 & $\overline{-203.21}$ \\
\hline & & std err & $0.30^{* * *}$ & $0.28 * * *$ & $0.23 * * *$ & $0.28 * * *$ & $0.33^{* * *}$ & 76.3 & 78.09 & 79.49 & $115.31 *$ & $115.31^{*}$ \\
\hline & \multirow{2}{*}{ urban } & coef & & 0.14 & 0.12 & 0.26 & 0.29 & & -172.43 & -164.68 & -41.49 & -41.49 \\
\hline & & std err & & 0.25 & 0.26 & 0.28 & 0.29 & & 113.2 & 105.83 & 139.42 & 139.42 \\
\hline & \multirow{2}{*}{ swing } & coef & & 0.02 & 0.04 & 0.49 & 0.59 & & -99.61 & -117.95 & -198.98 & -198.98 \\
\hline & & std err & & 0.29 & 0.31 & 0.32 & 0.41 & & 81.17 & 89.86 & 143.59 & 143.59 \\
\hline & \multirow{2}{*}{ observer (inst by pop) } & coef & & 0.04 & 0.04 & $\mathbf{0 . 0 3}$ & -0.07 & & 29.85 & 36.92 & 41.84 & 41.84 \\
\hline & & std err & & 0.06 & 0.06 & 0.05 & 0.21 & & $16.20^{*}$ & $19.07^{*}$ & 26.98 & 26.98 \\
\hline & \multirow{2}{*}{ Constant } & coef & 1.3 & 1.09 & 0.14 & -1.73 & -1.73 & -92.18 & -39.88 & 272.06 & 1883.09 & 1883.09 \\
\hline & & std err & $0.27 * * *$ & $0.33^{* * * *}$ & 0.74 & $0.99 *$ & $0.98^{*}$ & 59.73 & 81.97 & 217.85 & $540.00 * *$ & $540.00 * * *$ \\
\hline \multicolumn{3}{|c|}{ Demographic \& Psychological Controls } & No & No & Yes & Yes & Yes & No & No & Yes & Yes & $\begin{array}{l}\text { Yes } \\
\end{array}$ \\
\hline \multirow{2}{*}{\multicolumn{3}{|c|}{$\begin{array}{c}\text { Political Controls } \\
\text { Number of Observations }\end{array}$}} & No & No & No & Yes & Yes & No & No & No & Yes & Yes \\
\hline & & & 1013 & 1013 & 958 & 412 & 412 & 430 & 430 & 397 & 186 & 186 \\
\hline$\overline{\text { Adjusted I }}$ & -squared (OLS) F-stat (IV & & 0.02 & 0.02 & 0.06 & 0.14 & 5.19 & 0 & 0.02 & 0.02 & 0.11 & $5 \mathrm{E}+306$ \\
\hline
\end{tabular}

Note: Standard errors reported; these are corrected by clustering at the location (census area) level.

* significant at $10 \%$; ${ }^{* *}$ significant at $5 \%$; $* *$ significant at $1 \%$ 
Table A5: Regressions of Electoral Behavior (Turnout, Turnout Change, Vote Change)

\begin{tabular}{|c|c|c|c|c|c|c|c|c|c|c|}
\hline & \multicolumn{2}{|c|}{ Dependent Variable ------> } & \multirow{2}{*}{\multicolumn{8}{|c|}{$\begin{array}{c}\text { Turnout }(\mathrm{t}=\mathbf{0 , 1}) \\
\text { Probit }\end{array}$}} \\
\hline & & & & & & & & & & \\
\hline & & & & ME & & ME & & ME & & ME \\
\hline \multirow{4}{*}{$\begin{array}{c}\text { Main Explanatory } \\
\text { Variables }\end{array}$} & \multirow{2}{*}{$\begin{array}{l}\text { vb frequency (loc. } \\
\text { average/lagged) }\end{array}$} & coef & 0.11 & \multirow{2}{*}{0.02} & 0.11 & \multirow{2}{*}{0.02} & 0.1 & \multirow{2}{*}{0.01} & $\overline{0.13}$ & \multirow{2}{*}{0.01} \\
\hline & & std err & 0.04 **** & & $0.03^{* * *}$ & & $0.03^{* * *}$ & & $0.03 * * *$ & \\
\hline & \multirow{2}{*}{ Constant } & coef & 0.94 & \multirow{2}{*}{\multicolumn{3}{|c|}{\begin{tabular}{|c|}
$\mathbf{1 . 1 8}$ \\
$0.14 * * *$ \\
\end{tabular}}} & -0.59 & & -0.89 & \\
\hline & & std err & $0.15^{* * * *}$ & & & & 0.67 & & 0.72 & \\
\hline \multicolumn{3}{|c|}{ Structural Controls } & \multicolumn{2}{|c|}{$\overline{\text { No }}$} & \multicolumn{2}{|c|}{ Yes } & \multicolumn{2}{|c|}{ Yes } & \multicolumn{2}{|c|}{ Yes } \\
\hline \multicolumn{3}{|c|}{ Demographic \& Psychological Controls } & \multirow{2}{*}{\multicolumn{2}{|c|}{$\frac{\text { No }}{\text { No }}$}} & \multicolumn{2}{|c|}{ No } & \multicolumn{2}{|c|}{ Yes } & \multicolumn{2}{|c|}{ Yes } \\
\hline \multicolumn{3}{|c|}{ Political Controls } & & & \multirow{2}{*}{\multicolumn{2}{|c|}{$\begin{array}{l}\text { No } \\
2261\end{array}$}} & \multicolumn{2}{|c|}{ No } & \multicolumn{2}{|c|}{ Yes } \\
\hline \multirow{2}{*}{\multicolumn{3}{|c|}{ Number of Observations }} & \multicolumn{2}{|c|}{2261} & & & & & & \\
\hline & $\overline{R a t i o}$ Chi2 (P) & & \multicolumn{2}{|c|}{$\overline{8.54}$} & \multicolumn{2}{|c|}{18.13} & \multicolumn{2}{|c|}{240.34} & \multicolumn{2}{|c|}{382.1} \\
\hline
\end{tabular}

\begin{tabular}{|c|c|c|c|c|c|c|c|c|c|c|c|c|c|c|c|c|c|c|c|c|}
\hline & \multicolumn{2}{|c|}{ Dependent Variable ------> } & \multicolumn{9}{|c|}{ Change in Turnout } & \multicolumn{9}{|c|}{ Change in Vote } \\
\hline & & & \multicolumn{8}{|c|}{ Ordered Probit } & \multirow{2}{*}{ OLS } & \multicolumn{8}{|c|}{ Ordered Probit } & \multirow{2}{*}{ OLS } \\
\hline & & & & ME & & ME & & ME & & ME & & & ME & & ME & & ME & & ME & \\
\hline & treatment & \begin{tabular}{|l|} 
coef \\
std err
\end{tabular} & \begin{tabular}{c|c|}
-0.06 \\
0.14
\end{tabular} & -0.01 & $\begin{array}{c}-0.14 \\
0.14\end{array}$ & -0.03 & \begin{tabular}{c|c|}
-0.18 \\
0.14
\end{tabular} & -0.04 & \begin{tabular}{c|c|}
-0.22 \\
0.15
\end{tabular} & -0.04 & $\frac{-0.04}{0.03}$ & $\begin{array}{c}0.13 \\
0.1\end{array}$ & 0.05 & $\begin{array}{ll}\mathbf{0 . 1 6} \\
0.09^{*}\end{array}$ & 0.07 & \begin{tabular}{|c|}
$\mathbf{0 . 2 1}$ \\
$0.11^{* *}$ \\
\end{tabular} & 0.08 & \begin{tabular}{|c|}
$\mathbf{0 . 5 5}$ \\
$0.14^{* * * *}$ \\
\end{tabular} & 0.24 & \begin{tabular}{|c|}
$\mathbf{0 . 2 4}$ \\
$0.06^{* * *}$
\end{tabular} \\
\hline & Constant & \begin{tabular}{|l|} 
coef \\
std err
\end{tabular} & & & & & & & & & $\begin{array}{c}\mathbf{- 0 . 0 5} \\
0.08\end{array}$ & & & & & & & & & \begin{tabular}{|l|}
-1.04 \\
$0.31 * * *$
\end{tabular} \\
\hline \multicolumn{3}{|c|}{ Structural Controls } & \multicolumn{2}{|c|}{ No } & \multicolumn{2}{|c|}{ Yes } & \multicolumn{2}{|c|}{ Yes } & \multicolumn{2}{|c|}{ Yes } & Yes & \multicolumn{2}{|c|}{ No } & \multicolumn{2}{|c|}{ Yes } & \multicolumn{2}{|c|}{ Yes } & \multicolumn{2}{|c|}{ Yes } & Yes \\
\hline \multirow{2}{*}{\multicolumn{3}{|c|}{$\begin{array}{c}\text { Demographic \& Psychological Controls } \\
\text { Political Controls } \\
\end{array}$}} & \multirow{2}{*}{\multicolumn{2}{|c|}{$\begin{array}{l}\text { No } \\
\text { No }\end{array}$}} & \multirow{2}{*}{\multicolumn{2}{|c|}{$\begin{array}{l}\text { No } \\
\text { No }\end{array}$}} & \multirow{2}{*}{\multicolumn{2}{|c|}{$\begin{array}{l}\text { Yes } \\
\text { No }\end{array}$}} & \multirow{2}{*}{\multicolumn{2}{|c|}{ Yes }} & Yes & \multirow{2}{*}{\multicolumn{2}{|c|}{$\begin{array}{l}\text { No } \\
\text { No }\end{array}$}} & \multirow{2}{*}{\multicolumn{2}{|c|}{$\begin{array}{l}\text { No } \\
\text { No }\end{array}$}} & \multirow{2}{*}{\multicolumn{2}{|c|}{$\begin{array}{l}\text { Yes } \\
\text { No }\end{array}$}} & Ye & & Yes \\
\hline & & & & & & & & & & & Yes & & & & & & & Ye & & Yes \\
\hline & of Observation & & $\overline{10}$ & $\overline{34}$ & & 34 & & & & $\overline{96}$ & 496 & & $\overline{11}$ & 10 & & $90^{1}$ & & 382 & & 382 \\
\hline Lik Ratio Chi2 & Adjusted R-sq & OLS) & 0. & 18 & & 65 & 27 & & & .04 & 0.03 & & 72 & 6. & 15 & 46.6 & & 97.1 & & 0.08 \\
\hline
\end{tabular}

The upper table corresponds to a stacked regressions for pre and post-election data.

ME stands for Marginal Effects. Structural Controls are urban, tight, observers (in the lower table only). 
Table A6: Regressions of Actual Electoral Outcome (by Ballot Station)

\begin{tabular}{|c|c|c|c|c|c|c|}
\hline & \multicolumn{2}{|c|}{ Dependent Variable ------> } & \multicolumn{4}{|c|}{ "Difference Incumbent-Challenger $(t=1)$} \\
\hline & & & & OLS & & IV \\
\hline \multirow{8}{*}{$\begin{array}{c}\text { Main Explanatory } \\
\text { Variables }\end{array}$} & \multirow{2}{*}{ observer (inst by pop) } & coef & 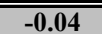 & & 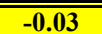 & (-0.3 \\
\hline & & std err & $0.02 *$ & & 0.02 & $0.11^{* * *}$ \\
\hline & \multirow{2}{*}{ treatment } & coef & & 0.07 & 0.06 & 0.03 \\
\hline & & std err & & $0.04 *$ & 0.04 & 0.05 \\
\hline & \multirow{2}{*}{ urban } & coef & & & 0.03 & -0.04 \\
\hline & & std err & & & 0.04 & 0.06 \\
\hline & \multirow{2}{*}{ Constant } & coef & 0.23 & 0.17 & 0.19 & 0.42 \\
\hline & & std err & $0.02^{* * *}$ & $0.02 * * *$ & $0.03^{* * *}$ & $0.10^{* * *}$ \\
\hline \multicolumn{3}{|c|}{ Number of Observations } & 228 & 228 & $\overline{2228}$ & 228 \\
\hline \multicolumn{3}{|c|}{ Adjusted R-squared (OLS) F-stat (IV) } & 0.01 & 0.01 & 0.02 & 3.45 \\
\hline
\end{tabular}

Note: Standard errors reported. ${ }^{*}$ significant at $10 \% ;{ }^{* *}$ significant at $5 \% ; * * *$ significant at $1 \%$ 
Table A7: Treatment Conformity Bias (Regressions of Outcomes on Treatment - Pre-election Only)

\begin{tabular}{|c|c|c|c|c|c|c|c|c|c|c|c|c|c|c|c|c|c|c|}
\hline & \multicolumn{2}{|c|}{ Dependent Variable ------> } & \multirow{2}{*}{\multicolumn{2}{|c|}{$\begin{array}{c}\begin{array}{c}\text { VB Frequency } \\
(\mathrm{t}=\mathbf{0})\end{array} \\
\text { OLS } \\
\end{array}$}} & \multirow{2}{*}{\multicolumn{2}{|c|}{$\frac{\text { VB Impact }(\mathbf{t}=\mathbf{0})}{\text { OLS }}$}} & \multirow{2}{*}{\multicolumn{2}{|c|}{$\begin{array}{c}\begin{array}{c}\text { Conscience } \\
\text { Voting }(t=0)\end{array} \\
\text { OLS }\end{array}$}} & \multirow{2}{*}{\multicolumn{2}{|c|}{$\begin{array}{c}\text { VB Value }(t=0) \\
\text { OLS }\end{array}$}} & \multirow{2}{*}{\multicolumn{4}{|c|}{ Turnout $(\mathrm{t}=\mathbf{0})$}} & \multirow{2}{*}{\multicolumn{4}{|c|}{$\begin{array}{c}\text { Vote }(\mathrm{t}=0) \\
\text { Ordered Probit }(-1,0,1)\end{array}$}} \\
\hline & & & & & & & & & & & & & & & & & & \\
\hline & & & & & & & & & & & & ME & & ME & & & & \\
\hline \multirow{4}{*}{$\begin{array}{c}\text { Main Explanatory } \\
\text { Variables }\end{array}$} & \multirow{2}{*}{ treatment } & coef & -0.19 & $\begin{array}{c}-0.38 \\
\end{array}$ & -0.01 & $-\overline{-0.06}$ & -0.5 & $\overline{-0.53}$ & 8.29 & 93.29 & -0.1 & \multirow{2}{*}{-0.01} & $\begin{array}{ll}-0.16 \\
\end{array}$ & \multirow{2}{*}{-0.02} & -0.09 & \multirow{2}{*}{-0.05} & -0.08 & \multirow{2}{*}{-0.05} \\
\hline & & std err & 0.22 & $0.22^{*}$ & 0.21 & 0.21 & $0.20^{* *}$ & $0.19^{* * *}$ & 129.65 & 116.72 & 0.18 & & 0.2 & & 0.16 & & 0.13 & \\
\hline & \multirow{2}{*}{ Constant } & coef & 4.83 & 3.06 & 4.63 & 3.82 & 4.24 & 4.3 & 258.39 & -338.35 & 1.55 & & 2.17 & & & & & \\
\hline & & std err & $0.19^{* * *}$ & $0.61^{* * *}$ & $0.19^{* * *}$ & $0.65^{* * *}$ & $0.19^{* * *}$ & $0.49 * * *$ & $112.47 * *$ & 277.65 & $0.16^{* * * *}$ & & $0.32^{\text {**** }}$ & & & & & \\
\hline \multicolumn{3}{|c|}{ Demographic \& Psychological \& Political Controls } & No & Yes & No & Yes & No & Yes & No & Yes & \multicolumn{2}{|c|}{ No } & \multicolumn{2}{|c|}{ Yes } & \multicolumn{2}{|c|}{ No } & \multicolumn{2}{|c|}{ Yes } \\
\hline \multicolumn{3}{|c|}{ Number of Observations } & 1232 & 1055 & 985 & 928 & 1004 & 908 & 951 & 697 & \multicolumn{2}{|c|}{1227} & \multicolumn{2}{|c|}{1225} & \multicolumn{2}{|c|}{1111} & \multicolumn{2}{|c|}{951} \\
\hline \multicolumn{3}{|c|}{ Adjusted R-squared (OLS) Lik Ratio Chi2 (P/OP) } & 0 & 0.09 & 0 & 0.02 & 0.02 & 0.04 & 0 & 0.07 & \multicolumn{2}{|c|}{0.28} & \multicolumn{2}{|c|}{8.52} & \multicolumn{2}{|c|}{0.28} & \multicolumn{2}{|c|}{83.39} \\
\hline
\end{tabular}


Table A8: Treatment Interacted with Demographics: are respondents that are affected by the campaign the same across the design?

\begin{tabular}{|c|c|c|c|c|c|c|c|c|c|c|}
\hline & & & \multicolumn{4}{|c|}{ Age $(*)$} & \multicolumn{4}{|c|}{ Schooling $(*)$} \\
\hline & \multicolumn{2}{|c|}{ Dependent Variable ------> } & $\begin{array}{l}\text { Change in } \\
\text { VB Impact }\end{array}$ & $\begin{array}{l}\text { Change in } \\
\text { Conscience } \\
\text { Voting }\end{array}$ & \multicolumn{2}{|c|}{ Change in Vote } & $\begin{array}{l}\text { Change in } \\
\text { VB Impact }\end{array}$ & $\begin{array}{c}\text { Change in } \\
\text { Conscience } \\
\text { Voting }\end{array}$ & \multicolumn{2}{|c|}{ Change in Vote } \\
\hline & & & OLS & OLS & \multicolumn{2}{|c|}{ Ordered Probit } & OLS & OLS & \multicolumn{2}{|c|}{ Ordered Probit } \\
\hline & & & & & & ME & & & & ME \\
\hline \multirow{8}{*}{$\begin{array}{c}\text { Main Explanatory } \\
\text { Variables }\end{array}$} & \multirow{2}{*}{ treatment } & coef & -0.42 & $\overline{0.58}$ & 0.32 & \multirow{2}{*}{0.14} & -1.67 & 1.79 & 0.71 & \multirow{2}{*}{0.31} \\
\hline & & std err & 0.76 & 0.57 & 0.48 & & $0.44^{* * * *}$ & $0.48^{* * *}$ & $0.26^{* * * *}$ & \\
\hline & \multirow{2}{*}{ treatment*demo $(*)$} & coef & -0.02 & 0.02 & 0.01 & \multirow[b]{2}{*}{$\mathbf{0}$} & 0.63 & -0.63 & -0.24 & \multirow{2}{*}{-0.1} \\
\hline & & std err & 0.02 & $0.01^{*}$ & 0.01 & & 0.49 & 0.47 & 0.37 & \\
\hline & \multirow{2}{*}{$\operatorname{demo}(*)$} & coef & 0.01 & $\mathbf{0}$ & 0.02 & \multirow[b]{2}{*}{0.01} & $\mathbf{0}$ & 0.26 & 0.45 & \multirow{2}{*}{0.19} \\
\hline & & std err & 0.02 & 0.01 & 0.01 & & 0.48 & 0.44 & 0.34 & \\
\hline & \multirow{2}{*}{ Constant } & coef & -0.49 & -1.08 & & & 1.44 & -1.85 & & \\
\hline & & std err & 1.24 & 1.03 & & & 1.04 & 1.21 & & \\
\hline \multicolumn{3}{|c|}{ Demographic \& Psychological \& Political Controls } & Yes & Yes & \multicolumn{2}{|c|}{ Yes } & Yes & Yes & \multicolumn{2}{|c|}{ Yes } \\
\hline \multicolumn{3}{|c|}{ Number of Observations } & 427 & 412 & \multicolumn{2}{|c|}{382} & 427 & 412 & \multicolumn{2}{|c|}{382} \\
\hline \multicolumn{3}{|c|}{ Adjusted R-squared (OLS) Lik Ratio Chi2 (OP) } & 0.09 & 0.14 & \multicolumn{2}{|c|}{103.57} & 0.09 & 0.14 & \multicolumn{2}{|c|}{105.22} \\
\hline & & & \multicolumn{4}{|c|}{ Occupation: Commerce(*) } & \multicolumn{4}{|c|}{ "Household Expenditure(*) } \\
\hline & Dependent Variable & $\ldots$ & $\begin{array}{l}\text { Change in } \\
\text { VB Impact }\end{array}$ & $\begin{array}{c}\text { Change in } \\
\text { Conscience } \\
\text { Voting }\end{array}$ & Chang̨ & ote & $\begin{array}{l}\text { Change in } \\
\text { VB Impact }\end{array}$ & $\begin{array}{c}\text { Change in } \\
\text { Conscience } \\
\text { Voting }\end{array}$ & Chang & ote \\
\hline & & & OLS & OLS & Order & obit & OLS & OLS & Order & obit \\
\hline & & & & & & ME & & & & ME \\
\hline & & coef & -1.14 & 1.19 & 0.52 & ר 20 & -3.45 & 1.8 & 1.56 & 068 \\
\hline & treatment & std err & $0.33^{* * *}$ & $0.38^{* * *}$ & $0.17 * * *$ & 0.22 & $1.11^{* * *}$ & $0.46^{* * *}$ & $0.58^{* * *}$ & 0.68 \\
\hline & treatment*demo $(*)$ & coef & -0.55 & 0.83 & 0.15 & & 2.27 & -0.43 & -1.06 & -0.46 \\
\hline Main Explanatory & treatment"demo(") & std err & 0.59 & 0.66 & 0.27 & 0.07 & $1.10^{* *}$ & 0.51 & $0.59^{*}$ & -0.46 \\
\hline Variables & $\operatorname{demo}(*)$ & coef & 0.63 & -0.62 & -0.18 & 0.07 & -2.64 & 0.3 & 0.97 & 043 \\
\hline & demo(*) & std err & 0.52 & 0.62 & 0.25 & -0.07 & $0.94 * * *$ & 0.38 & $0.51^{*}$ & 0.43 \\
\hline & & coef & 0.06 & -1.55 & & & 1.72 & -2.06 & & \\
\hline & Constant & std err & 1.1 & 0.99 & & & 1.44 & $1.07^{*}$ & & \\
\hline Demographic \& & chological \& Political & ntrols & Yes & Yes & & & Yes & Yes & & \\
\hline & er of Observations & & 425 & 412 & & & 427 & 4411 & & \\
\hline Adjusted R-sq & ed (OLS) Lik Ratio Cl & (OP) & 0.09 & 0.14 & & & 0.09 & 0.13 & & \\
\hline
\end{tabular}

Note: Standard errors reported; these are corrected by clustering at the location (census area) level.

* significant at $10 \%$; $* *$ significant at $5 \% ; * * *$ significant at $1 \%$. 
Table A9: Regressions of Outcomes on Distance to Closest Treatment Area (Control Locations Only)

\begin{tabular}{|c|c|c|c|c|c|c|c|c|c|}
\hline \multicolumn{2}{|c|}{ Dependent Variable ------> } & \multirow[t]{3}{*}{$\begin{array}{l}\text { Change in VB } \\
\text { Frequency }\end{array}$} & \multirow{3}{*}{$\begin{array}{c}\text { Change in VB } \\
\text { Impact } \\
\end{array}$} & \multirow{2}{*}{$\begin{array}{c}\text { Change in } \\
\text { Conscience } \\
\text { Voting } \\
\end{array}$} & \multirow[t]{3}{*}{$\begin{array}{c}\text { Change in VB } \\
\text { Value }\end{array}$} & \multicolumn{2}{|c|}{ Change in Turnout } & \multicolumn{2}{|c|}{ Change in Vote } \\
\hline & & & & & & & Order & robit & \\
\hline & & & & & & & ME & & ME \\
\hline \multirow{2}{*}{ distance to treatment } & coef & -0.2 & -0.16 & 0.08 & 2.64 & -0.06 & \multirow{2}{*}{$-\mathbf{0 . 0 1}$} & 0.02 & \multirow{2}{*}{0.01} \\
\hline & std err & $0.10^{*}$ & 0.1 & 0.09 & 8.96 & 0.05 & & 0.04 & \\
\hline \multirow{2}{*}{ Constant } & coef & -1.44 & -0.62 & 1.11 & -98.24 & & & & \\
\hline & std err & $0.41^{* * *}$ & $0.20^{* *}$ & $0.34^{* *}$ & 74.01 & & & & \\
\hline \multicolumn{2}{|c|}{ Number of Observations } & 215 & 218 & 221 & 82 & \multicolumn{2}{|c|}{226} & \multicolumn{2}{|c|}{220} \\
\hline \multicolumn{2}{|c|}{ Adjusted R-squared (OLS) Lik Ratio Chi2 (OP) } & 0.01 & 0.02 & 0 & -0.01 & \multicolumn{2}{|c|}{1.2} & \multicolumn{2}{|c|}{0.35} \\
\hline
\end{tabular}

